The Canadian Mineralogist

Vol. 50, pp. 675-692 (2012)

DOI : 10.3749 /canmin.50.3.675

\title{
TEXTURAL VARIATIONS IN MORB SULFIDE DROPLETS DUE TO DIFFERENCES IN CRYSTALLIZATION HISTORY
}

\author{
CLIFFORD PATTEN \\ Module des Sciences de la Terre, Université du Québec à Chicoutimi, Chicoutimi, Québec, G7H 2B1, \\ Canada.clifford.patten@uqac.ca \\ SARAH-JANE BARNES \\ Module des Sciences de la Terre, Université du Québec à Chicoutimi, Chicoutimi, Québec, G7H 2B1, \\ Canada.sjbarnes@uqac.ca \\ EDMOND A. MATHEZ \\ Department of Earth \& Planetary Sciences, American Museum of Natural History, New York, NY 1002, \\ United States of America.mathez@amnh.org
}

\begin{abstract}
Sulfide droplets from fresh Mid-Ocean-Ridge Basalt (MORB) glasses show different textures. Some are fine-grained droplets consist of Monosulfide Solid Solution (Mss) and Intermediate Solid Solution (Iss) micrometric intergrowths with pentlandite at the Mss-Iss interface and disseminated Fe-oxide grains; other droplets display a characteristic "zoned" texture consisting of segregated massive grains of Mss and Iss, with euhedral Fe-oxides and pentlandite occuring as equant grains and as flame-shaped domains in the Mss formed by exsolutions. The difference in the textures implies a difference in the crystallization history of the sulfide droplets. These different textures are observed in droplets that are only millimeters apart in the same sample, and thus had an identical cooling history. Therefore, some other factors controlled the textural development. There is relationship between the size and the texture of the droplets. The larger sulfide droplets tend to have zoned textures and the smaller ones fine-grained textures. We propose that the latter have experienced greater undercooling before crystallization. The reason for the delay in crystallization could be that, in the small sulfide droplets, large stable grains with low surface to volume ratio cannot form, which results in higher effective solubility of the Mss. Due to the high degree of undercooling in the small droplets, there were numerous nucleation sites and the diffusion rates of the crystal components in the liquid were lower, leading to fine-grained Mss-Iss intergrowths. In contrast, larger droplets with lower effective solubility of Mss began to crystallize at higher temperature, and thus had fewer nucleation sites, higher diffusion rates, and more time for sulfide differentiation.
\end{abstract}

Keywords: sulfide droplet, mid-ocean-ridge basalt, monosulfide solid solution, intermediate solid solution, effective solubility, crystallization.

\section{INTRODUCTION}

Fresh Mid-Ocean-Ridge Basalt (MORB) glasses contain sulfide droplets with a wide range of textures, for which few explanations exist (e.g., Mathez \& Yeats 1976, Czamanske \& Moore 1977). Upon eruption, MORB quench from $\sim 1200{ }^{\circ} \mathrm{C}$ to seawater temperature in less than a few minutes (Moore 1975). In addition, because the quenching occurs under pressures of the deep ocean, MORBs typically do not undergo substantial degassing (Mathez 1976). Sulfides occur as micrometric spherules embedded in the walls of large vesicles (Moore \& Calk 1971, Moore \& Schilling 1973, Yeats \& Mathez 1976), as small angular interstitial grains in microcrystalline aggregates of plagioclase and olivine (Mathez \& Yeats 1976), and as well-developed spherical globules, mostly in the glass or, in some cases, in phenocrysts (Mathez \& Yeats 1976, Czamanske \& Moore 1977). The well developed droplets represent frozen immiscible sulfide melt believed to have equilibrated with the silicate melt before eruption (Mathez \& Yeats 1976).

§E-mail address: clifford.patten@uqac.ca, clifford.patten@geo.su.se 
The globules in the glass have different textures. The textures vary from fine-grained intergrowth of Monosulfide Solid Solution (Mss) and Intermediate Solid Solution (Iss), to coarser-grained intergrowth of Mss and Iss with pentlandite and oxide (Mathez 1976, Czamanske \& Moore 1977). Mathez \& Yeats (1976) and Czamanske \& Moore (1977) suggested that such samples quenched from $\sim 1200{ }^{\circ} \mathrm{C}$ to $700-600{ }^{\circ} \mathrm{C}$ in tens of seconds. With such rapid cooling one might expect the texture of droplets to be similar. Yet this is not the case.

The textures displayed by sulfide droplets are controlled by component nucleation and the diffusion rates which, in turn, are controlled by factors that remain unknown. Czamanske \& Moore (1977) speculated that droplets displaying fine-grained textures may have undergone more rapid cooling than coarsegrained droplets. They did not speculate on cause of the textural variability, but did note that it is not linked to the distance of the droplet from the lava surface, i.e., not linked to cooling rate.

In this study, 24 samples of fresh glass of MORB pillow margins from various locations were examined for sulfide droplets. Eighty-five droplets were found in 11 samples. Twenty-five were analyzed by electron microprobe and show a rather constant bulk composition while displaying a wide variation of textures. In some samples, sulfide droplets have different textures, although the droplets segregated from the same magma have the same composition, and were subjected to the same quench event. Therefore, neither sulfide droplet composition nor cooling rate are the main factors controlling the textures of the droplets. Instead we observe a correlation between the droplet textures and the size.

The aims of this study are (1) to describe in detail the textures of the sulfide droplets, and (2) to understand how droplet size can influence the texture.

\section{SAmpling And Analytical Methods}

Samples come from the repository at the Lamont Doherty Earth Observatory of Columbia University, New York. Twenty-four samples, mainly from the South Atlantic Ridge and the East Pacific Rise, were investigated, of which 11 were found to contain sulfide droplets large enough to study. Six of these are from the South Atlantic Ridge, located between $25^{\circ} 41^{\prime} \mathrm{S}$ and $26^{\circ} 32$ 'S; the other five samples are from the East Pacific Rise, two from the Hotu seamount chain and three from the Garrett fracture zone. All samples were dredged from depths ranging from 2579 to $3999 \mathrm{~m}$. Fragments of fresh glass were hand-picked from the most external parts of pillow lavas, with care being taken to avoid Mn-coated parts.

The sulfide droplets were observed optically in reflected light with an Olympus DP 71 microscope at $100 \times$ magnification coupled with the Image Pro Plus
Analysis 6.2 image analysis package. Modes were calculated from pictures based on pixel colors representative of each phase. To gain a sense of the precision of the measurements, modes were measured five times on an individual sulfide droplet, yielding a sample standard deviation of 1.9, 1.3, 1.2, and $0.6 \%$ for Mss, Iss, Ni-rich phase, and oxide, respectively. The variation reflects the ability of the observer to choose the right pixel colors for each phase. On one small droplet with a diameter of $10 \mu \mathrm{m}$ sample standard variations of $6.5,6.8$, and $5.2 \%$ for Mss, Iss, and the Ni-rich phase were recorded owing to the difficulty of observing such small objects. Therefore, the minimum size of the analyzed sulfide droplets was set at $10 \mu \mathrm{m}$.

Electron Probe Micro Analyses (EPMA) were carried out using a CAMECA SX-100 instrument at Laval University, Québec city. Both sulfide droplets and the surrounding glass were analyzed. For sulfide minerals, an accelerating voltage of $15 \mathrm{kV}$, a beam diameter of $5 \mu \mathrm{m}$, and a beam current of $20 \mathrm{nA}$ were used, as advocated by Czamanske \& Moore (1977), with a counting time of $20 \mathrm{sec}$. The same settings were used for the analysis of silicate glass. They are similar to those used by Liu et al. (2007) and Wallace \& Carmichael (1992). Astimex standards were used for calibration: pyrite for $\mathrm{S}$, hematite for $\mathrm{Fe}$, chalcopyrite for $\mathrm{Cu}$, and pentlandite for Ni. Astimex and P\&H Development standards were used for major elements in the glass.

For droplets having a fine-grained texture, three points were taken randomly and the averages were used for the bulk-composition calculation as the beam was too broad to analyze each phase separately. For droplets having coarser textures, analyses were obtained for each individual sulfide phase, and the droplet bulk composition was determined from the relative areas occupied by each phase on the analytical surface.

For each sulfide droplet analyzed, three points on the surrounding glass were also analyzed. The analytical points were $100 \mu \mathrm{m}$ away from the droplet border in order to avoid possible contamination due to dispersion of elements from the droplets to the glass or X-ray fluorescence in the sample (Dalton \& Lane 1996). The quenched sulfide droplets and fresh MORB glass are believed to reflect an equilibrium established at magmatic conditions (Mathez 1976).

\section{RESULTS}

All samples have a glass composition typical of low-K tholeiitic basalt and are N-MORB, except for two samples from the seamounts that might be E-MORB (Table 1). Sulfur concentrations, which range from 782 to $1530 \mathrm{ppm}$ (Table 1), are similar to those found by Mathez (1979) and Czamanske \& Moore (1977) and correlate with $\mathrm{FeO}$ concentration in the glass (Fig. 1).

Among the 15 polished sections containing sulfide droplets, we observed 85 sulfide droplets with diameters $\geq 10 \mu \mathrm{m}$. The majority are spherical and the remainder 


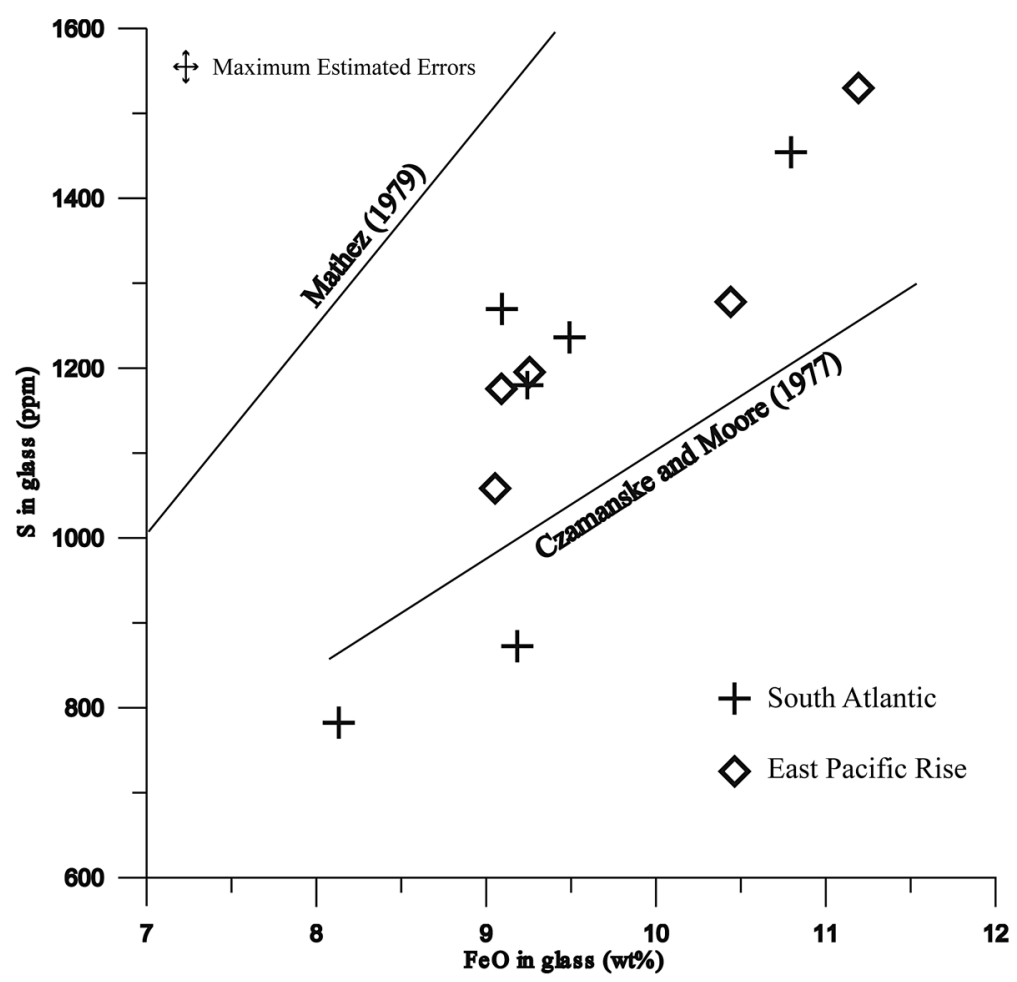

FIG. 1. Positive correlation of sulfur content and FeO concentration in the glass. The values lie between those determined by Mathez (1979) and Czamanske \& Moore (1977).

are elliptical. The sulfide droplets vary from 10 to more than $100 \mu \mathrm{m}$ in diameter (average of $27 \mu \mathrm{m}$ ). This size range is similar to that observed by Moore \& Calk (1971), Mathez \& Yeats (1976), and Mathez (1976), in their samples. Larger droplets, up to $600 \mu \mathrm{m}$, have been found in MORB (Czamanske \& Moore 1977, Peach et al. 1990), but were not encountered in our samples. The number of sulfide droplets and their sizes vary from sample to sample; some contain numerous small droplets, whereas others have fewer but larger droplets. For example, RC 2802 22rd contains 39 droplets varying in diameter from $5 \mu \mathrm{m}$ up to $40 \mu \mathrm{m}$ (average of $18 \mu \mathrm{m}$ ), whereas RC 2802 18rd has only three droplets ranging from 56 to $111 \mu \mathrm{m}$.

The formation of sulfide droplets from the silicate liquid was considered by Mungall (2002). He suggested that sulfide nucleation density in the silicate liquid depends on the degree of saturation of the principal solute species FeS, in the magma. Recently, Holzeid (2010) showed that the sulfide droplets size distribution is controlled by the degree of polymerization of the silicate liquid.

\section{The texture of sulfide droplets}

Sulfide droplets can be classified into three groups based on texture. The first includes droplets with perfectly spherical shapes and composed of fine-grained micrometric intergrowths of $\mathrm{Fe}-\mathrm{Ni}$-rich and $\mathrm{Cu}-\mathrm{Fe}$-rich sulfide phases, which can be interpreted as quenched Mss and Iss (Fig. 2). In some droplets, the Mss-Iss interfaces are partially rimmed by a Ni-rich phase, presumably pentlandite or Ni-rich Mss.

A second group of droplets has a quasi-perfect spherical shape, but with some sub-micrometric irregularities giving them a rough surface. They also contain intergrown $\mathrm{Fe}-\mathrm{Ni}$-rich and $\mathrm{Cu}-\mathrm{Fe}$-rich phases interpreted as quenched Mss and Iss. However, the sizes of the phases are larger than in the fine-grained textures (Fig. 3). Accordingly, these droplets will be referred to as having a coarse-grained texture. The Ni-rich grains present at the Mss-Iss interfaces are larger than the Ni-rich grains in the fine-grained droplets. In some droplets, Ni-rich inclusions in the shape of flame are present within the Mss. These are interpreted as exsolution-induced 

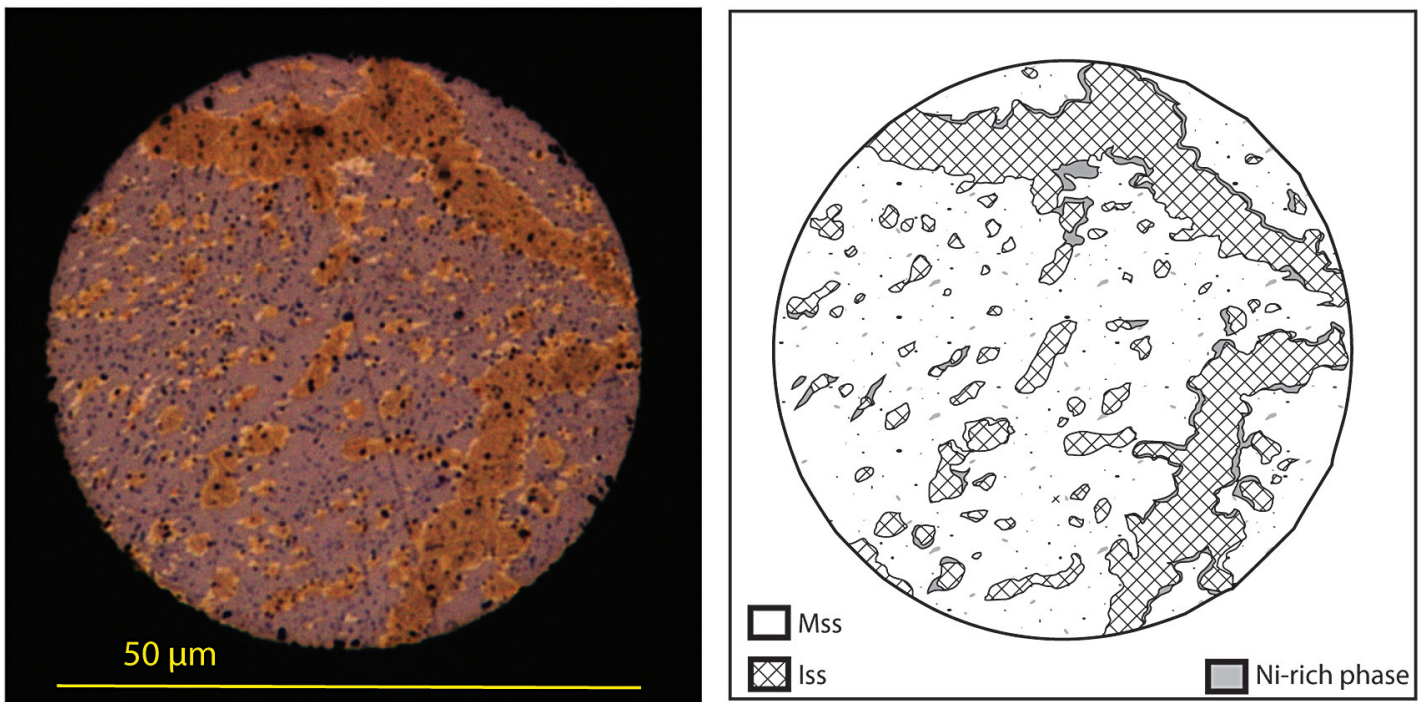

FIG. 2. Photomicrograph illustrating the textural character of a fine-grained sulfide droplet (sample RC 280224 rd). Note the perfect spherical shape of the droplet. Mss and Iss are finely intergrowth and contain grains of Ni-rich phase at their interface.
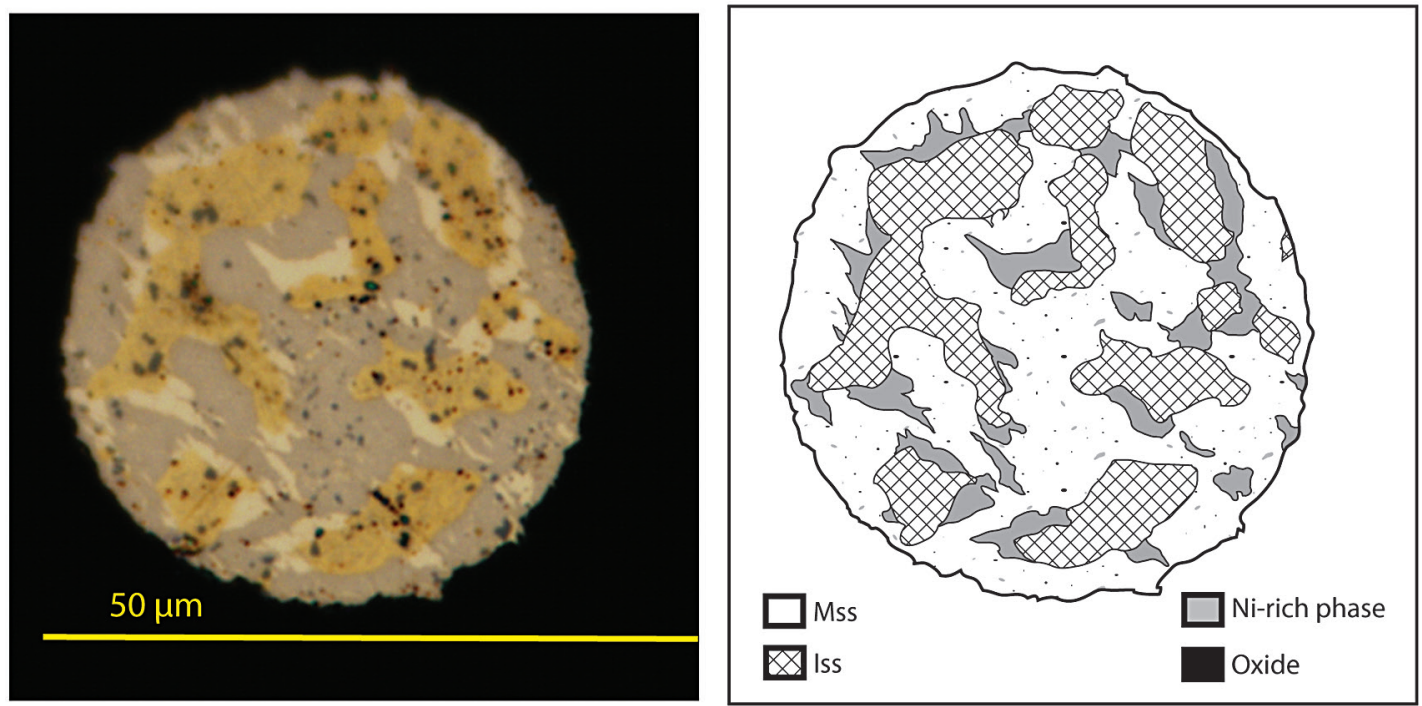

FIG. 3. Photomicrograph illustrating the textural character of a coarse-grained sulfide droplet (sample Cook D37 t.IV). Note the quasi-perfect spherical shape. Mss and Iss are intergrowth as in fine-grained droplets (Fig. 2), but there are fewer grains and they are larger. The Ni-rich phase is present both at the Mss-Iss interface and as flame-shaped grains inside Mss.

domains (Kelly \& Vaughan 1983, Etschmann et al. 2004, Czamanske \& Moore 1977). The droplets also contain dark opaque phases interpreted as oxides.

A third texture will be referred to as zoned because it consists of two distinct, massive, and completely separate grains of Mss and Iss (Fig. 4). Droplets with this texture are spherical and have crenulated contacts with the silicate glass (Figs. 4a, b, c), in contrast to the smooth and regular interfaces of other droplet types and their host glasses. These droplets have not been 
described in previous studies of MORB sulfide droplets. The Mss is massive whereas the Iss reveals two different textures. The most common is one in which the Iss and oxide form a fishbone texture (Figs. 4a, b). This microassemblage can be interpreted as the residual $\mathrm{Cu}$-rich sulfide-oxide liquid that remained after the Mss crystallization. Alternatively, the Iss is massive and may contain euhedral oxide grains (Fig. 4c). Pentlandite occurs in zoned droplets at the Mss and Iss interface and as flame inclusions in the MSS. Flame-shaped domains are more common than in the coarse-grained droplets. Because the Mss and Iss are not homogeneously distributed within the zoned droplet, the exposed proportions of minerals may not be representative of the whole droplet, and there is a higher variability in the modal percentage of each phase and their distribution inside the droplets. The zoned droplets are similar in texture to centimeter-size pyrrhotite-chalcopyrite-pentlandite magmatic sulfide blebs found in dykes and subvolcanic sills (e.g., Prichard et al. 2004, Barnes et al. 2006).

\section{Relationship between diameter and texture}

Sulfide droplets with different textures may coexist in the same sample. For example, of the eight droplets from sample RC 2802 13rd, four are fine-grained, three are coarse-grained, and one is zoned. Of the 14 polished sections, five contain droplets with different textures. Czamanske \& Moore (1977) observed no relationship between the distance from the surface pillow and the texture of the droplets. In the samples of this study, droplets exhibiting different textures are separated by only a few millimeters within homogeneous fresh glass, confirming Czamanske's \& Moore's (1977) observations.

Most of the droplets (75\%) show a fine-grained texture. Coarse-grained textured droplets are the next most common (15\%), and zoned droplets are the least common $(10 \%)$. There appears to be a relationship between the size of the droplets and their texture (Fig. 5). Over $90 \%$ of the fine-grained droplets have diameters less than $30 \mu \mathrm{m}$. In contrast, in the 30-50 $\mu \mathrm{m}$ range $60 \%$ of the sulfide droplets are coarse-grained. Of the droplets greater than $50 \mu \mathrm{m}$, all are zoned. It appears, therefore, that there is a positive correlation between the increase in droplet diameter and the degree of segregation of the phases. It could be argued that this is based on observations of random sections through droplets that do not reflect their real droplet diameters. This must be partly true; however, the fine-grained droplets do not represent the outer portion of larger zoned droplets because the margins of the latter are uniquely crenulated, while those of the former are smooth. In addition, a section through the margin of a zoned droplet would consist predominantly of either Mss or Iss and not show a fine intergrowth of Mss and Iss. Moreover, even though in Figure 5 some zoned sulfide droplets have small apparent diameters, which might be external sections of the droplets, the fine-grained sulfide droplets never exceed $50 \mu \mathrm{m}$, implying that they are generally smaller. Hence, the relations observed in Figure 5 are qualitatively valid. We conclude that the internal texture of the droplets is related to size.

\section{Composition of the sulfide droplets}

Sulfide phase relations in the system $\mathrm{Fe}-\mathrm{Ni}-\mathrm{Cu}-\mathrm{S}$ have been widely studied for the understanding of ore deposit formation (Craig \& Kullerud 1969, Naldrett 1969, Fleet \& Pan 1994, Ebel \& Naldrett 1997, Mungall et al. 2005, Mungall 2007). The bulk compositions of sulfide droplets were calculated to $100 \%$ sulfide in order to estimate liquidus temperature of the Mss using the results of Ebel \& Naldrett (1997), which pertain to $\mathrm{O}$-free systems. The results are listed in Table 2 and the calculations are documented in Appendix 1. The calculated compositions display low variability in $\mathrm{S}$ content $(34.9 \pm 0.98 \%)$, moderate variability in Fe content (46.8 $\pm 3.69 \%)$, and high variability in $\mathrm{Ni}(7.8 \pm 3.69 \%)$ and $\mathrm{Cu}$ contents $(8.4 \pm 3.51 \%)$. Concentrations of $\mathrm{Ni}$ and $\mathrm{Cu}$ in the sulfide droplets are dependent on their partition coefficient and on the initial composition of the magma.

Figure 6 presents the bulk compositions of our sulfide droplets in terms of the system $\mathrm{Fe}-\mathrm{Ni}-\mathrm{Cu}$. The results show a range in bulk compositions and are in agreement with previous work (Mathez 1976, Czamanske \& Moore 1977). One coarse grained droplet of $48 \mu \mathrm{m}$ from sample RC $280207 \mathrm{rd}$ contains up to $24.7 \% \mathrm{Ni}$. This droplet contains a large proportion of the Ni-rich phase $(28.8 \%)$, which can be attributed to the $226 \mathrm{ppm} \mathrm{Ni}$ contained in the whole rock (Appendix 2). The dashed lines on Figure 6 represent the composition of the sulfide liquid at crystallization of the Mss for 1100,1050 , and $1000{ }^{\circ} \mathrm{C}$ from Ebel \& Naldrett (1997, Fig. 5), which gives approximations of the liquidus temperature of the sulfide droplets. The liquidus temperatures range from slightly above 1100 to $1050{ }^{\circ} \mathrm{C}$, and the droplets are randomly spread over this interval regardless of their texture. Hence, there appears to be no relationship between texture and composition.

\section{Occurrence of magnetite}

Oxide occurs either inside Mss, inside Iss, or at their interface (Figs. 2, 3, and 4) and varies from nil to $7 \%$ of the droplet. In zoned droplets, where the oxide grains are best developed, electron microprobe analyses reveal that they are magnetite free of Ti (Appendix 3), indicating that magnetite crystallizes from the sulfide liquid and did not equilibrate with the silicate liquid. Magnetite is also present at the edges of the sulfide droplets (Fig. 4), but in grains too small to be analyzed, and in a fishbone texture in the $\mathrm{Cu}$-rich quenched residual sulfide liquid found in some zoned droplets 
(Figs. 4a,b) ( $c f$. Naldrett 1969, Skinner \& Peck 1969). In a few fine-grained droplets oxides were not observed; however, Czamanske \& Moore (1977) suggested that a few percent of magnetite is ubiquitous in droplets.

\section{DISCUSSION}

To explain textural differences among sulfide droplets, one could argue that they are related to the time they started to crystallize. In such a model large sulfide droplets grew and begin to crystallize before eruption and thus also had time to develop zoned textures, and small ones formed during eruption at lower temperatures.

Using the PELE 7.3 database (Boudreau, 1999) and glass data from Table 1, the liquidus temperatures of the silicate melts are calculated to be in the $1250-1170{ }^{\circ} \mathrm{C}$ range. Figure 6 indicates that Mss starts to crystallize in sulfide droplets at $\sim 1100{ }^{\circ} \mathrm{C}$. Hence, large sulfide droplets could not have started crystallizing before eruption. Moreover, analyses of fine-grained and coarse-grained sulfide droplets and the surrounding glass (Patten et al., in prep.) show that the concentrations of chalcophile and siderophile elements in these droplets are similar to the zoned ones and that there is no depletion in those elements in the surrounding glass, implying they had time to equilibrate with the silicate melt. Hence, small sulfide droplets are likely to have formed before the eruption and, like their larger brethren, did not start to crystallize before the eruption.

\section{Processes of crystallization}

The formation of sulfide droplets in silicate melts is considered by Mungall (2002). The textures observed in the sulfide droplets indicate variations in their crystallization histories. The development of the crystals involves three processes: nucleation, diffusion, and growth, all of which are characterized by rates that vary according to circumstances (Shelley 1993). The Mss is the first phase to crystallize from $\mathrm{Fe}-\mathrm{Ni}-\mathrm{Cu}$ sulfide liquid (e.g., Fleet \& Pan 1994, Ebel \& Naldrett 1997, Mungall 2007). Nucleation can either be homogeneous or heterogeneous. In the case of homogeneous nucleation the total energy of a spherical nucleus $(\Delta G)$ of Mss in a sulfide liquid is the sum of its internal energy and its surface energy (e.g., Mungall \& Su 2005):

TABLE 1. BULK COMPOSITION OF THE GLASS

\begin{tabular}{|c|c|c|c|c|c|c|c|c|c|c|c|c|c|}
\hline \multicolumn{2}{|c|}{ Sample List } & $\begin{array}{l}\mathrm{SiO}_{2} \\
\text { wt. \% }\end{array}$ & $\begin{array}{c}\mathrm{TiO}_{2} \\
\text { wt. \% }\end{array}$ & $\begin{array}{r}\mathrm{Al}_{2} \mathrm{O}_{3} \\
\text { wt. \% }\end{array}$ & $\begin{array}{l}\mathrm{FeO} \\
\text { wt.\% }\end{array}$ & $\begin{array}{r}\mathrm{Cr}_{2} \mathrm{O}_{3} \\
\text { wt. \% }\end{array}$ & $\begin{array}{l}\mathrm{MgO} \\
\text { wt.\% }\end{array}$ & $\begin{array}{l}\mathrm{CaO} \\
\text { wt. } \%\end{array}$ & $\begin{array}{l}\mathrm{MnO} \\
\text { wt.\% }\end{array}$ & $\begin{array}{l}\mathrm{Na}_{2} \mathrm{O} \\
\text { wt. } \%\end{array}$ & $\begin{array}{l}\mathrm{K}_{2} \mathrm{O} \\
\text { wt. } \%\end{array}$ & $(\mathrm{ppm})$ & Total \\
\hline \multicolumn{14}{|c|}{ South Atlantic Ridge } \\
\hline \multirow[t]{2}{*}{ RC 2802 07rd } & $n=3$ & 49.6 & 1.2 & 17.0 & 9.2 & 0.04 & 8.9 & 11.2 & 0.2 & 2.9 & 0.05 & 873 & 100.5 \\
\hline & $\sigma$ & 0.12 & 0.01 & 0.05 & 0.11 & 0.04 & 0.09 & 0.04 & 0.04 & 0.03 & 0.01 & 88 & 0.26 \\
\hline \multirow[t]{2}{*}{ RC 2802 13rd } & $n=12$ & 50.3 & 1.6 & 15.1 & 9.5 & 0.07 & 8.0 & 11.4 & 0.2 & 2.7 & 0.09 & 1253 & 99.3 \\
\hline & $\sigma$ & 0.20 & 0.04 & 0.06 & 0.17 & 0.04 & 0.06 & 0.04 & 0.03 & 0.03 & 0.01 & 81 & 0.31 \\
\hline \multirow[t]{2}{*}{ RC 2802 16rd } & $n=15$ & 50.4 & 1.4 & 14.7 & 9.1 & 0.05 & 7.7 & 12.2 & 0.2 & 2.8 & 0.05 & 1275 & 98.7 \\
\hline & $\sigma$ & 0.31 & 0.04 & 0.10 & 0.23 & 0.03 & 0.09 & 0.10 & 0.03 & 0.06 & 0.01 & 86 & 0.57 \\
\hline \multirow[t]{2}{*}{ RC 2802 18rd } & $n=3$ & 51.6 & 1.1 & 15.3 & 8.1 & 0.08 & 8.4 & 12.8 & 0.1 & 2.7 & 0.05 & 782 & 100.4 \\
\hline & $\sigma$ & 0.26 & 0.07 & 0.07 & 0.13 & 0.02 & 0.44 & 0.36 & 0.01 & 0.80 & 0.01 & 272 & 0.43 \\
\hline \multirow[t]{2}{*}{ RC 2802 22rd } & $n=9$ & 51.4 & 1.8 & 14.0 & 10.8 & 0.01 & 7.0 & 11.3 & 0.2 & 3.0 & 0.07 & 1454 & 99.9 \\
\hline & $\sigma$ & 0.13 & 0.04 & 0.04 & 0.19 & 0.02 & 0.06 & 0.05 & 0.03 & 0.03 & 0.01 & 88 & 0.23 \\
\hline \multirow[t]{2}{*}{ RC 2802 24rd } & $n=8$ & 50.5 & 1.6 & 15.6 & 9.2 & 0.06 & 8.2 & 11.5 & 0.2 & 2.8 & 0.07 & 1180 & 99.8 \\
\hline & $\sigma$ & 0.19 & 0.05 & 0.06 & 0.15 & 0.04 & 0.05 & 0.05 & 0.02 & 0.06 & 0.01 & 100 & 0.43 \\
\hline \multicolumn{14}{|c|}{ Hotu Sea Mount } \\
\hline \multirow[t]{2}{*}{ Cook D3 tIII } & $n=3$ & 47.9 & 2.9 & 15.4 & 11.2 & 0.0 & 6.2 & 9.7 & 0.2 & 3.3 & 0.72 & 1530 & 97.9 \\
\hline & $\sigma$ & 0.27 & 0.08 & 0.19 & 0.09 & 0.02 & 0.10 & 0.02 & 0.02 & 0.05 & 0.01 & 47 & 0.39 \\
\hline \multirow[t]{2}{*}{ Cook D19 tl n1 } & $n=3$ & 47.6 & 2.2 & 16.9 & 10.4 & 0.07 & 7.5 & 10.1 & 0.2 & 3.3 & 0.58 & 1278 & 99.0 \\
\hline & $\sigma$ & 0.18 & 0.04 & 0.06 & 0.12 & 0.05 & 0.02 & 0.04 & 0.02 & 0.06 & 0.01 & 25 & 0.36 \\
\hline \multicolumn{14}{|c|}{ East Pacific Rise } \\
\hline \multirow[t]{2}{*}{ Cook D28 tl } & $n=9$ & 48.8 & 1.4 & 16.0 & 9.0 & 0.07 & 8.5 & 11.9 & 0.2 & 3.1 & 0.12 & 1054 & 99.3 \\
\hline & $\sigma$ & 0.10 & 0.05 & 0.43 & 0.31 & 0.05 & 0.27 & 0.03 & 0.03 & 0.10 & 0.01 & 94 & 0.27 \\
\hline \multirow[t]{2}{*}{ Cook D37 tIV } & $n=6$ & 48.7 & 1.3 & 16.6 & 9.3 & 0.02 & 8.3 & 11.7 & 0.2 & 2.9 & 0.12 & 1195 & 99.4 \\
\hline & $\sigma$ & 0.25 & 0.05 & 0.07 & 0.13 & 0.02 & 0.03 & 0.09 & 0.02 & 0.02 & 0.01 & 58 & 0.36 \\
\hline \multirow[t]{2}{*}{ Cook D37 tVI } & $n=18$ & 48.6 & 1.2 & 16.7 & 9.1 & 0.05 & 8.5 & 11.7 & 0.2 & 2.8 & 0.11 & 1167 & 99.2 \\
\hline & & 0.29 & 0.06 & 0.10 & 0.13 & 0.03 & 0.08 & 0.03 & 0.02 & 0.04 & 0.01 & 86 & 0.45 \\
\hline
\end{tabular}

$n=$ number of analyses; $\sigma=$ sample standard deviation.

Note that samples from the South Atlantic Ridge are slightly richer in $\mathrm{SiO}_{2}$ and samples from the Hotu Sea Mounts are slightly richer in $\mathrm{TiO}_{2}$ and $\mathrm{K}_{2} \mathrm{O}$.

Data acquired by EPMA. 

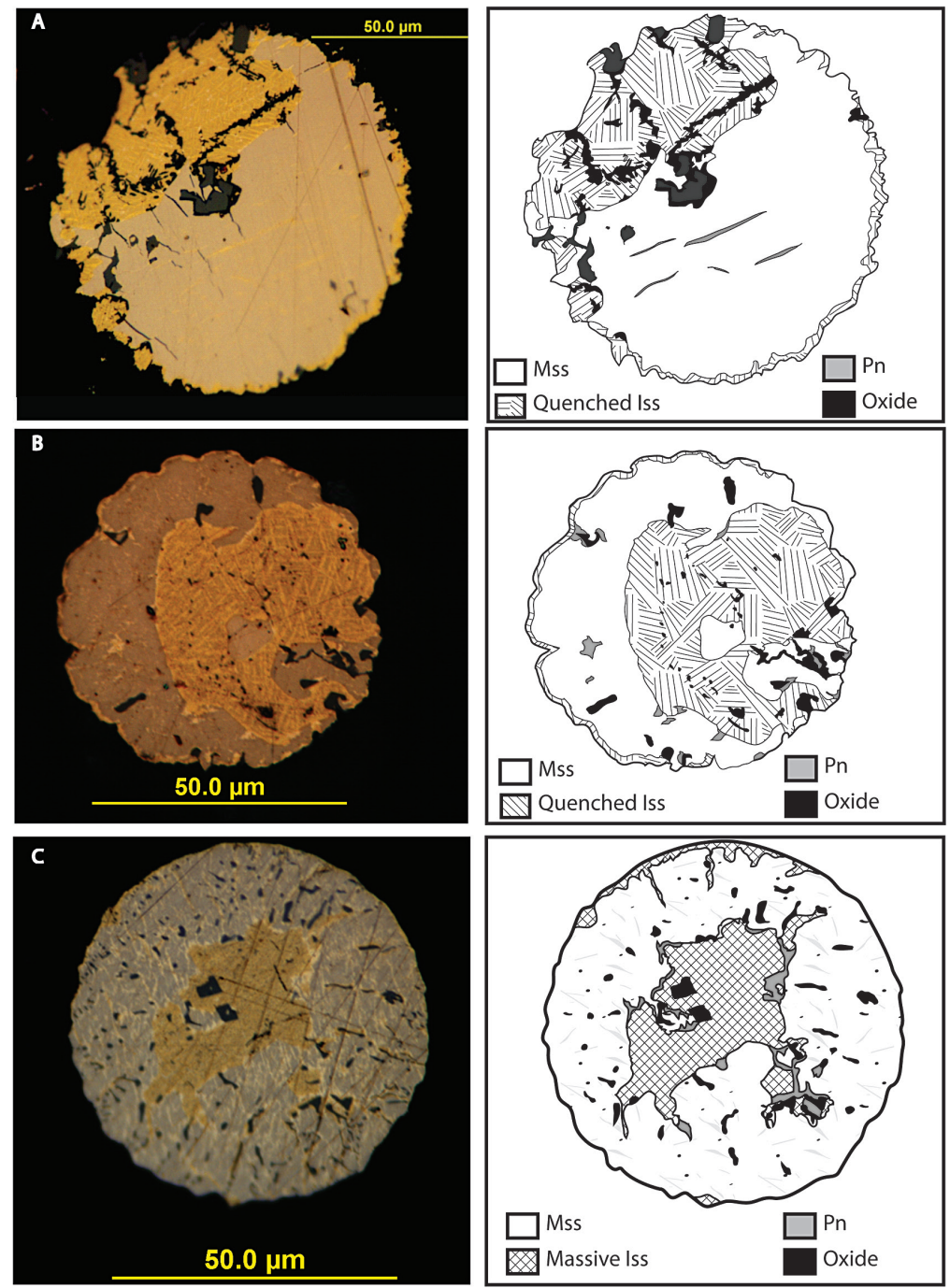

FIG. 4. Photomicrographs illustrating the textural character of zoned sulfide droplets. Droplet A is from sample RC 2802 18rd, droplet B is from sample RC 2802 13rd, and droplet C is from sample Cook D19 tI. Note their crenulated contacts with surrounding glass. Droplets A and B have quenched Iss with fishbone texture and droplet $\mathrm{C}$ has massive Iss and euhedral oxide. Pentlandite (Pn) is present as lozenge-flame-shaped grains within Mss and as grains at the Mss-Iss interface.

$$
\Delta G=\frac{4 \Delta G_{C}}{3 \pi r^{3} V_{m}}+4 \pi r^{2} \gamma
$$

where $\Delta \mathrm{G}_{\mathrm{C}}$ is the free energy per mole of the Mss crystal, $r$ the radius of the nucleus, $\mathrm{V}_{\mathrm{m}}$ the molar volume of the Mss, and $\gamma$ the interfacial tension between Mss and sulfide liquid. At formation, the nucleus has a very large ratio of surface area to volume, implying that the surface energy is relatively high owing to the large number of atoms not electrostatically balanced (Shelley 1993). This energy makes the nucleus unstable and leads it to shrink (Dowty 1980). A certain amount of energy is needed to overcome the force of the surface energy in order to reach a critical radius from which the nucleus will grow spontaneously. This energy is called 
TABLE 2. BULK COMPOSITION OF THE SULFIDE DROPLETS

\begin{tabular}{|c|c|c|c|c|c|c|c|c|}
\hline \multirow[t]{2}{*}{ Droplet } & \multirow[t]{2}{*}{ Texture } & \multirow{2}{*}{$\frac{\text { Size }}{\mu m}$} & \multirow{2}{*}{$\frac{n}{(\text { phase })^{*}}$} & \multicolumn{5}{|c|}{ Bulk composition (wt.\%) } \\
\hline & & & & s & $\mathrm{Ni}$ & $\mathrm{Cu}$ & $\mathrm{Fe}$ & Total \\
\hline $\begin{array}{l}\mathrm{RC} 2802 \text { 07rd G1 } \\
\sigma\end{array}$ & Coarse-grained & 48 & $\begin{array}{l}9 \\
(1.2 .3)\end{array}$ & $\begin{array}{c}34.46 \\
0.90\end{array}$ & $\begin{array}{c}15.93 \\
3.91\end{array}$ & $\begin{array}{c}11.36 \\
1.86\end{array}$ & $\begin{array}{c}37.21 \\
1.93\end{array}$ & 98.95 \\
\hline $\begin{array}{l}\text { RC } 2802 \text { 13rd n1 G6 } \\
\sigma\end{array}$ & Zoned & 63 & $\begin{array}{l}4 \\
(1.2)\end{array}$ & $\begin{array}{c}35.81 \\
0.96\end{array}$ & $\begin{array}{l}7.70 \\
0.71\end{array}$ & $\begin{array}{c}12.17 \\
1.52\end{array}$ & $\begin{array}{l}44.07 \\
0.87\end{array}$ & 99.76 \\
\hline $\begin{array}{l}\text { RC } 2802 \text { 13rd n1 G10 } \\
\sigma\end{array}$ & Fine-grained & 29 & $\begin{array}{l}2 \\
(4)\end{array}$ & $\begin{array}{c}35.61 \\
0.89\end{array}$ & $\begin{array}{l}8.93 \\
0.13\end{array}$ & $\begin{array}{l}2.68 \\
1.78\end{array}$ & $\begin{array}{c}50.39 \\
1.24\end{array}$ & 97.61 \\
\hline $\begin{array}{l}\mathrm{RC} 2802 \text { 13rd n2 G1 } \\
\sigma\end{array}$ & Fine-grained & 28 & $\begin{array}{l}3 \\
(4)\end{array}$ & $\begin{array}{c}34.97 \\
0.54\end{array}$ & $\begin{array}{l}8.30 \\
0.65\end{array}$ & $\begin{array}{l}3.64 \\
0.83\end{array}$ & $\begin{array}{c}48.87 \\
1.24\end{array}$ & 95.78 \\
\hline $\begin{array}{l}\text { RC } 2802 \text { 13rd n2 G2 } \\
\sigma\end{array}$ & Fine-grained & 13 & $\begin{array}{l}3 \\
(4)\end{array}$ & $\begin{array}{c}35.58 \\
0.52\end{array}$ & $\begin{array}{l}8.94 \\
0.85\end{array}$ & $\begin{array}{l}4.98 \\
1.34\end{array}$ & $\begin{array}{c}48.60 \\
1.99\end{array}$ & 98.11 \\
\hline $\begin{array}{l}\text { RC } 2802 \text { 13rd n2 G3 } \\
\sigma\end{array}$ & Fine-grained & 12 & $\begin{array}{l}3 \\
(4)\end{array}$ & $\begin{array}{c}35.66 \\
0.51\end{array}$ & $\begin{array}{l}9.37 \\
0.55\end{array}$ & $\begin{array}{l}3.70 \\
0.75\end{array}$ & $\begin{array}{c}48.88 \\
0.68\end{array}$ & 97.62 \\
\hline $\begin{array}{l}\text { RC } 280216 d n 1 \text { G10 } \\
\sigma\end{array}$ & Fine-grained & 45 & $\begin{array}{l}3 \\
(1.2)\end{array}$ & $\begin{array}{c}33.69 \\
0.44\end{array}$ & $\begin{array}{l}3.49 \\
0.03\end{array}$ & $\begin{array}{c}14.52 \\
1.10\end{array}$ & $\begin{array}{c}45.53 \\
0.28\end{array}$ & 97.22 \\
\hline $\begin{array}{l}\text { RC } 2802 \text { 16rd n1 G3 } \\
\sigma\end{array}$ & Fine-grained & 21 & $\begin{array}{l}3 \\
(4)\end{array}$ & $\begin{array}{c}34.51 \\
0.26\end{array}$ & $\begin{array}{l}3.56 \\
0.66\end{array}$ & $\begin{array}{l}11.31 \\
2.87\end{array}$ & $\begin{array}{c}47.06 \\
1.85\end{array}$ & 96.44 \\
\hline $\begin{array}{l}\text { RC } 280216 r d n 1 G 4 \\
\sigma\end{array}$ & Fine-grained & 25 & $\begin{array}{l}3 \\
(4)\end{array}$ & $\begin{array}{c}34.78 \\
0.34\end{array}$ & $\begin{array}{l}4.42 \\
0.28\end{array}$ & $\begin{array}{l}7.52 \\
0.17\end{array}$ & $\begin{array}{c}50.14 \\
0.59\end{array}$ & 96.86 \\
\hline $\begin{array}{l}\text { RC } 2802 \text { 16rd n2 G2 } \\
\sigma\end{array}$ & Zoned & 18 & $\begin{array}{l}2 \\
(1.2) \sigma=0\end{array}$ & 32.43 & 2.19 & 13.92 & 46.98 & 95.53 \\
\hline $\begin{array}{l}\text { RC } 2802 \text { 16rd n2 G6 } \\
\sigma\end{array}$ & Fine-grained & 20 & $\begin{array}{l}3 \\
(4)\end{array}$ & $\begin{array}{c}33.67 \\
0.20\end{array}$ & $\begin{array}{l}3.11 \\
1.25\end{array}$ & $\begin{array}{l}15.52 \\
4.70\end{array}$ & $\begin{array}{c}44.99 \\
3.37\end{array}$ & 97.30 \\
\hline $\begin{array}{l}\text { RC } 2802 \text { 18rd G5 } \\
\sigma\end{array}$ & Zoned & 70 & $\begin{array}{l}4 \\
(1.2)\end{array}$ & $\begin{array}{c}37.81 \\
0.16\end{array}$ & $\begin{array}{l}6.10 \\
0.55\end{array}$ & $\begin{array}{l}4.38 \\
0.89\end{array}$ & $\begin{array}{l}51.75 \\
0.73\end{array}$ & 100.03 \\
\hline $\begin{array}{l}\mathrm{RC} 2802 \text { 22rd G25 } \\
\sigma\end{array}$ & Fine-grained & 29 & $\begin{array}{l}3 \\
(4)\end{array}$ & $\begin{array}{c}34.32 \\
0.32\end{array}$ & $\begin{array}{l}3.16 \\
0.24\end{array}$ & $\begin{array}{l}6.59 \\
0.29\end{array}$ & $\begin{array}{c}52.73 \\
1.03\end{array}$ & 96.81 \\
\hline $\begin{array}{l}\mathrm{RC} 2802 \text { 22rd G26 } \\
\sigma\end{array}$ & Fine-grained & 26 & $\begin{array}{l}3 \\
(4)\end{array}$ & $\begin{array}{c}34.62 \\
0.12\end{array}$ & $\begin{array}{l}2.95 \\
0.17\end{array}$ & $\begin{array}{l}8.88 \\
1.44\end{array}$ & $\begin{array}{c}50.85 \\
0.91\end{array}$ & 97.29 \\
\hline $\begin{array}{l}\mathrm{RC} 2802 \text { 22rd G29 } \\
\sigma\end{array}$ & Fine-grained & 41 & $\begin{array}{l}3 \\
(4)\end{array}$ & $\begin{array}{c}34.72 \\
0.16\end{array}$ & $\begin{array}{l}2.84 \\
0.56\end{array}$ & $\begin{array}{l}8.67 \\
3.71\end{array}$ & $\begin{array}{c}51.44 \\
2.56\end{array}$ & 97.67 \\
\hline $\begin{array}{l}\mathrm{RC} 280224 \mathrm{rd} G 2 \\
\sigma\end{array}$ & Fine-grained & 33 & $\begin{array}{l}3 \\
(1.2)\end{array}$ & $\begin{array}{c}34.49 \\
0.90\end{array}$ & $\begin{array}{l}9.23 \\
0.36\end{array}$ & $\begin{array}{c}10.48 \\
3.43\end{array}$ & $\begin{array}{c}43.88 \\
2.47\end{array}$ & 98.09 \\
\hline $\begin{array}{l}\mathrm{RC} 280224 \mathrm{rd} G 3 \\
\sigma\end{array}$ & Fine-grained & 50 & $\begin{array}{l}3 \\
(1.2)\end{array}$ & $\begin{array}{c}34.73 \\
0.28\end{array}$ & $\begin{array}{l}8.42 \\
0.62\end{array}$ & $\begin{array}{l}9.06 \\
3.09\end{array}$ & $\begin{array}{c}44.85 \\
2.10\end{array}$ & 97.06 \\
\hline $\begin{array}{l}\mathrm{RC} 280224 \mathrm{rd} G 6 \\
\sigma\end{array}$ & Coarse-grained & 38 & $\begin{array}{l}4 \\
(1.2 .3)\end{array}$ & $\begin{array}{c}35.49 \\
1.15\end{array}$ & $\begin{array}{c}10.53 \\
1.07\end{array}$ & $\begin{array}{l}4.54 \\
0.11\end{array}$ & $\begin{array}{c}47.71 \\
1.45\end{array}$ & 98.27 \\
\hline $\begin{array}{l}\text { Cook D19 tl n1 G2 } \\
\sigma\end{array}$ & Zoned & 62 & $\begin{array}{l}5 \\
(1.2)\end{array}$ & $\begin{array}{c}33.94 \\
2.28\end{array}$ & $\begin{array}{c}12.71 \\
0.44\end{array}$ & $\begin{array}{l}6.48 \\
1.50\end{array}$ & $\begin{array}{c}44.83 \\
1.44\end{array}$ & 97.96 \\
\hline $\begin{array}{l}\text { Cook D28 tl n1 G1 } \\
\sigma\end{array}$ & Coarse-grained & 32 & $\begin{array}{l}4 \\
(1.2)\end{array}$ & $\begin{array}{c}35.54 \\
1.45\end{array}$ & $\begin{array}{c}10.76 \\
1.09\end{array}$ & $\begin{array}{l}4.50 \\
1.63\end{array}$ & $\begin{array}{c}47.74 \\
1.37\end{array}$ & 98.54 \\
\hline $\begin{array}{l}\text { Cook D28 tl n2 G1 } \\
\sigma\end{array}$ & Coarse-grained & 42 & $\begin{array}{l}4 \\
(1.2)\end{array}$ & $\begin{array}{c}34.50 \\
1.04\end{array}$ & $\begin{array}{c}11.26 \\
1.92\end{array}$ & $\begin{array}{l}9.72 \\
1.19\end{array}$ & $\begin{array}{c}43.53 \\
0.18\end{array}$ & 99.01 \\
\hline $\begin{array}{l}\text { Cook D37 tIV G2 } \\
\sigma\end{array}$ & Coarse-grained & 32 & $\begin{array}{l}5 \\
(1.2 .3)\end{array}$ & $\begin{array}{c}35.16 \\
1.32\end{array}$ & $\begin{array}{l}8.87 \\
0.72\end{array}$ & $\begin{array}{c}10.05 \\
0.85\end{array}$ & $\begin{array}{c}44.47 \\
0.57\end{array}$ & 98.55 \\
\hline $\begin{array}{l}\text { Cook D37 tVI n2 G1 } \\
\sigma\end{array}$ & Coarse-grained & 20 & $\begin{array}{l}3 \\
(4)\end{array}$ & $\begin{array}{c}35.05 \\
0.56\end{array}$ & $\begin{array}{c}11.35 \\
0.92\end{array}$ & $\begin{array}{l}4.78 \\
1.42\end{array}$ & $\begin{array}{c}45.60 \\
1.14\end{array}$ & 96.78 \\
\hline $\begin{array}{l}\text { Cook D37 tVI n2 G3 } \\
\sigma\end{array}$ & Fine-grained & 13 & $\begin{array}{l}3 \\
(4)\end{array}$ & $\begin{array}{c}35.12 \\
0.10\end{array}$ & $\begin{array}{l}9.26 \\
2.09\end{array}$ & $\begin{array}{c}11.80 \\
3.75\end{array}$ & $\begin{array}{c}43.26 \\
1.45\end{array}$ & 99.44 \\
\hline $\begin{array}{l}\text { Cook D37 tVI n3 G8 } \\
\sigma\end{array}$ & Zoned & 15 & $\begin{array}{l}3 \\
(4)\end{array}$ & $\begin{array}{c}35.10 \\
0.39\end{array}$ & $\begin{array}{c}10.99 \\
1.11\end{array}$ & $\begin{array}{l}8.38 \\
0.75\end{array}$ & $\begin{array}{c}43.58 \\
0.43\end{array}$ & 98.05 \\
\hline
\end{tabular}

* Phases analyzed: (1) Fe-rich, (2) Cu-rich, (3) Ni-rich, and (4) whole droplet. $\sigma=$ sample standard deviation.

For fine-grained droplets, bulk compositions were calculated with whole droplet microprobe analysis. For coarse-grained and zoned sulfide droplets, bulk compositions are calculated by combining microprobe data on the different sulfide phases and Image Pro Plus 6.1 data using equation [6]. Details in Appendix 1 and Table 3. 


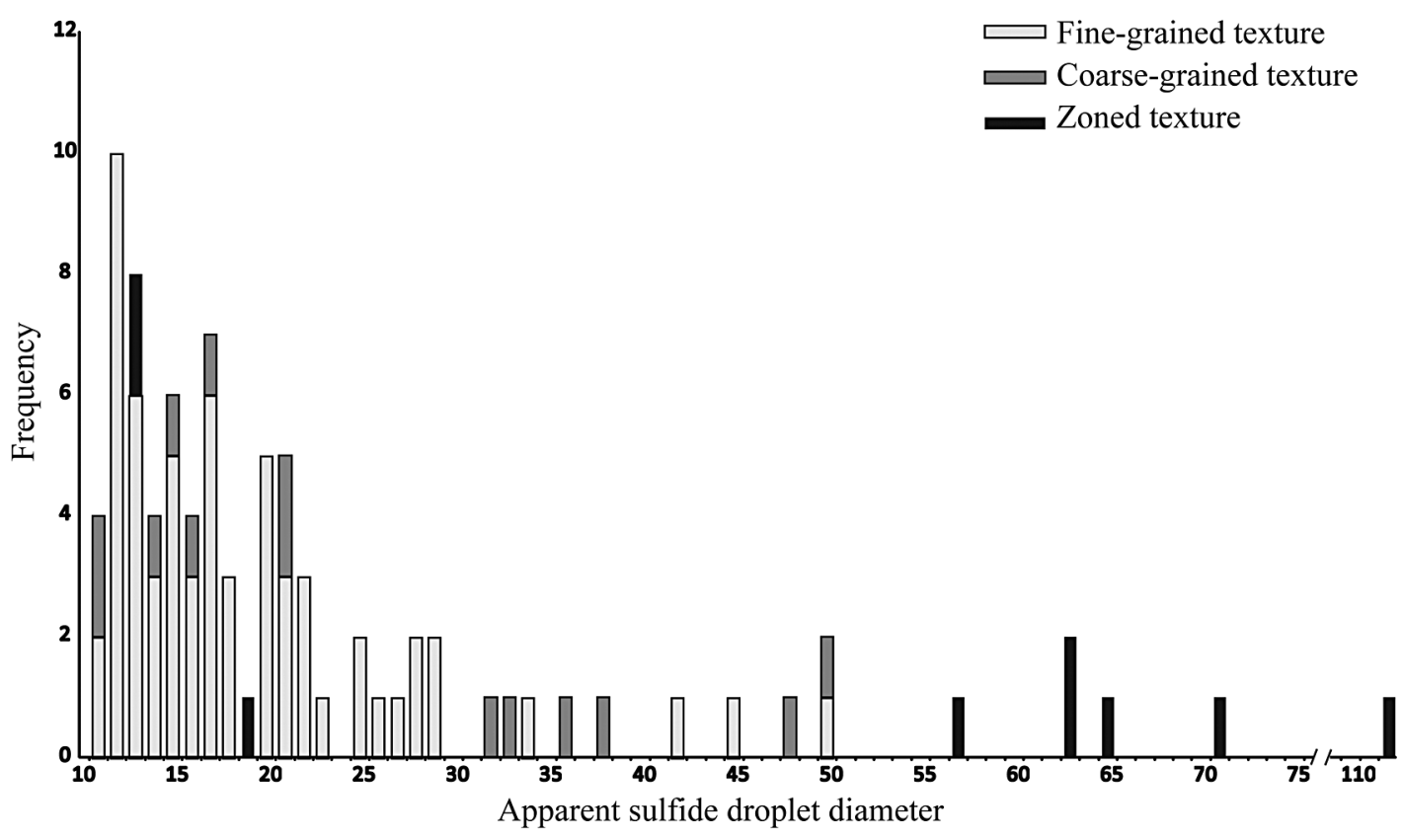

FIG. 5. Frequencies of apparent sulfide droplet diameters and textural types. Note that sulfide droplets with diameters larger than $50 \mu \mathrm{m}$ have a zoned texture.

free energy of activation (Dowty 1980) or nucleation energy barrier (Shelley 1993). The critical radius $\left(r_{C}\right)$ is defined as (e.g., Dowty 1980):

$$
r_{C}=-2 \gamma V_{m} / \Delta G_{C}
$$

The nucleation rate is dependent on the degree of undercooling: as the latter increases, the nucleation rate reaches a maximum, and then declines to zero at high degrees of undercooling (Shelley 1993). The undercooling is the extra amount of cooling sustained by the droplet from its freezing point before it starts to crystallize. The undercooling delays crystallization and leads it to occur at lower temperature. Much work has been done on silicate nucleation rates using crystalsize distribution (CSD) (e.g., Gibb 1974, Dowty 1980, Cashman \& Marsh 1988, Higgins 2006), but none on sulfides are known to the authors.

Heterogeneous nucleation can occur on preexisting interfaces. The surface energy of heterogeneous nucleation is lower than that of homogeneous nucleation in equation 2 , and thus the size needed for nucleus stability is also lower (e.g., Mungall \& Su 2005). Heterogeneous nucleation needs less undercooling to occur.

Once nuclei are created, diffusion to the nuclei occurs by volume diffusion (the diffusion of elements in a liquid), and the nuclei grow by interface diffusion (across the crystal-liquid interface) and surface diffu- sion (parallel to the surface) (Dowty 1980). Diffusion rates decrease with the undercooling (Shelley 1993) and systems with high undercooling will not contain fully grown crystals.

\section{Implications of crystallization rates on the textures}

As described above, fine-grained droplets contain numerous small intergrowths of Mss and Iss. During crystallization, numerous nucleation sites were created randomly inside the droplet and diffusion was slow, preventing crystal growth from occurring. Thus, finegrained droplets have experienced substantial undercooling followed by rapid crystallization. This process could be interpreted as homogeneous nucleation.

Coarse-grained droplets have the same textural features as fine-grained droplets, but the grains are larger and less numerous. They developed because there were fewer nucleation sites and more rapid diffusion, suggesting a lower degree of undercooling. These features could also suggest homogeneous nucleation. As can be seen in Figure 6, the bulk compositions of finegrained and coarse-grained droplets are similar. Hence, in order to explain the higher rate of crystal growth, the degree of undercooling must have been lower.

Zoned droplets contain massive Mss and Iss. This texture must have required a lower rate of nucleation and higher rate of diffusion than in the fine-grained and 
coarse-grained droplets. The presence of segregated Mss and Iss in zoned droplets suggests that sufficient time elapsed between the appearance of Mss and that of the complete solidification of the droplet for the fractionated $\mathrm{Cu}-\mathrm{Fe}$-rich liquid to migrate away from the Mss. Moreover, as described above, the Iss in the zoned droplets exist either as fishbone textured grains, representing quenched residual $\mathrm{Cu}-\mathrm{Fe}$-rich sulfide liquid and implying a relatively high degree of undercooling, or as equant, massive grains representing the crystallization of Iss and implying a relatively low degree of undercooling.

The nucleation process of the zoned sulfide droplets is not clearly defined. In the sulfide droplet of Figure $4 \mathrm{c}$, the Mss is concentrated on the outer part of the droplet and the massive Iss is concentrated in the center. Such texture may have developed by heterogeneous nucleation of Mss crystals on the sulfide droplet wall. Other zoned sulfide droplets do not show this arrangement, suggesting that heterogeneous nucleation from the droplet wall is not the dominant crystallization mechanism.

One could argue that fine-grained and coarse-grained sulfide droplets formed by homogeneous nucleation and that zoned sulfide droplets are formed by heterogeneous nucleation. If heterogeneous nucleation on the droplet wall is a major process, small droplets should be more likely to show zoned textures than larger droplets because they have a higher surface to volume ratio, but this is not observed. Moreover, such interpretation does not take into account the continuum of textural differences from fine-grained to zoned with massive Iss owing to different rates of crystallization. Therefore, we believe that both homogeneous and heterogeneous nucleation can occur, but that they are not the main parameters controlling the textures.

\section{Why are the small droplets more undercooled?}

The texture of the small fine-grained sulfide droplets implies higher degree of undercooling than large zoned droplets. Observations on droplet sphericity tend to confirm this inference. As pointed out by Czamanske \& Moore (1977), the perfect sphericity of fine-grained sulfide droplets implies that they were still liquid when the silicate liquid reached the glass transition, whereas zoned droplets, with crenulated sphericity, had already started to crystallize at that point.

Emmanuel et al. (2010) argued that during nucleation and crystal growth the solubility of a phase is related to the change of the interfacial energy of the phase. Because small crystals have high surface to

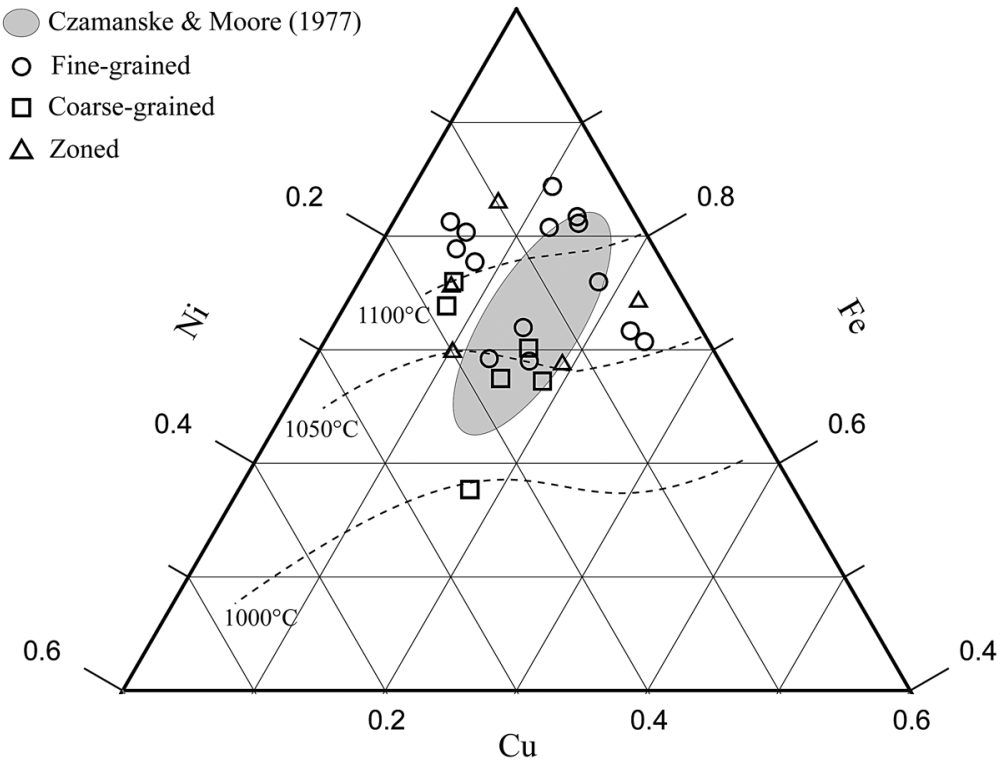

FIG. 6. Bulk composition of sulfide droplets in the system $\mathrm{Fe}-\mathrm{Ni}-\mathrm{Cu}$ in weight fraction. The grey zone corresponds to the bulk composition of sulfide droplets from Czamanske \& Moore (1977). Dashed line represents the composition of sulfide liquid composition at Mss crystallization at 1100,1050 , and $1000{ }^{\circ} \mathrm{C}$ from Ebel \& Naldrett (1997). Note that texture of sulfide droplets is not dependent on their composition. Droplet liquidii range between more than 1100 to $1050{ }^{\circ} \mathrm{C}$. Modified from Czamanske and Moore (1977). 
volume ratios, high interfacial diffusivity is required to maintain chemical equilibrium, which in turn requires a more concentrated solution before nucleation and growth can occur (Holness \& Sawyer 2008). This concentration is referred to as the effective solubility $S_{\mathrm{e}}$. When a crystal forms in a confined volume, the effective solubility becomes a function of the radius of that volume (Emmanuel et al. 2010):

$$
S_{e}=S_{0} \exp \left(\frac{2 V_{m} \gamma}{R T r_{s}}\right)
$$

where $\mathrm{S}_{0}$ is the bulk solubility, $\mathrm{R}$ the gas constant, $\mathrm{T}$ the temperature, and $r_{S}$ the radius of the confined volume, i.e., the sulfide droplet.

The volume influence on the effective solubility leads to supersaturation of the phase components in the solution; such an effect has been observed in porous sedimentary rocks (Emmanuel et al. 2010, Putnis \& Mauthe 2001) and in small pores in migmatites (Holness \& Sawyer 2008). Because the solution is supersaturated, high undercooling is needed for crystallization to occur (Bigg 1953, Putnis \& Mauthe 2001, Holness \& Sawyer 2008).

The sulfide droplet can be considered as a confined volume because the interfacial tension between sulfide melt and silicate melt is relatively high; higher than those between silicate or oxide minerals and silicate melt (Mungall \& Su 2005). Therefore, the size of the sulfide droplet has an influence on the Mss solubility: small sulfide droplets require a higher concentration of Mss liquid components before Mss can crystallize than larger sulfide droplets.

It would be interesting to investigate the critical size of the volume at which the effective solubility of Mss in the sulfide liquid is affected. Quartz crystallization in sandstone does not occur in pores smaller than $10 \mu \mathrm{m}$ (Emmanuel et al. 2010). Putnis \& Mauthe (2001) argued that supersaturation occurs if pore size is around $1 \mu \mathrm{m}$ and does not occur for pores larger than $100 \mu \mathrm{m}$. Bigg (1953) observed that a water droplet of $10 \mu \mathrm{m}$ could crystallize at $-31{ }^{\circ} \mathrm{C}$, sustaining high undercooling. Although these systems are different from those dealt with in this paper; the size relation remains relevant. More than $90 \%$ of fine-grained sulfide droplets have a diameter lower than $30 \mu \mathrm{m}$, whereas droplets with a diameter greater than $50 \mu \mathrm{m}$ are zoned.

\section{Implication of the undercooling of sulfide droplets on solidification history}

The different solidification histories experienced by the different droplets are summarized in Figure 7. As stated above, the crystallization of Mss in fine-grained and coarse-grained droplets is delayed (Fig. 7, $3^{\text {rd }}$ and $4^{\text {th }}$ columns). Once the Mss starts to crystallize, it is quickly followed by the crystallization of Iss. The residual $\mathrm{Cu}-\mathrm{Fe}$-rich liquid did not have time to migrate away from the Mss, leading to the characteristic intergrowth of Mss and Iss observed in these droplets (Fig. 2 and 3 ).

Zoned sulfide droplets (Fig. 7, $1^{\text {st }}$ and $2^{\text {nd }}$ column) experience less undercooling, allowing more time for diffusion and thus enabling formation of equant Mss grains. Those zoned droplets which experienced somewhat greater degrees of undercooling crystallize Iss with oxide in a fishbone texture (Fig. $4 \mathrm{a}$ and b). Those that experienced slightly lower degrees of undercooling form massive Iss crystals containing equant oxide crystals (Fig. 4c).

These differences in crystallization histories must have an impact on the distribution of chalcophile trace elements and the noble metals inside the sulfide droplets. In the fine- and coarse-grained sulfide droplets the trace elements should be relatively homogeneously distributed, as the diffusion rates were low. However, in the zoned sulfide droplets, because the diffusion rates were higher, the trace elements should have had time to fractionate between Mss and Iss.

\section{Pentlandite content of sulfide droplets}

The pentlandite content of the sulfide droplets is variable (Fig. 8). Where whole-rock concentrations of $\mathrm{Ni}$ are low (less than $50 \mathrm{ppm}$ ), pentlandite does not form and the $\mathrm{Ni}$ (Appendix 2) concentration in the Mss is less than $10 \%$. In samples with higher whole-rock concentrations of $\mathrm{Ni}$, the pentlandite can constitute up to $27 \%$ of the droplets, and concentrations of $\mathrm{Ni}$ in the Mss are also higher but never exceed $15 \%$. These observations imply that even in rapidly quenched system Mss can absorb no more than 15 wt.\% Ni before pentlandite exsolves. It appears that the amount of pentlandite in the sulfide droplets is dependent on the initial concentration of the magma, and not on the degree of undercooling.

In fine-grained sulfide droplets, pentlandite occurs as blebs or rims at the Mss-Iss interface (Fig. 2), suggesting formation by heterogeneous nucleation at the interface. In coarse-grained droplets, pentlandite also occurs at Mss-Iss interfaces but is more lozengeflame-shape. According to Kelly \& Vaughan (1983), this characteristic shape is formed by heterogeneous nucleation, but apparently under lower undercooling. Czamanske \& Moore (1977) considered such coarse pentlandite to have exsolved at close to its maximum temperature of stability $\left(610{ }^{\circ} \mathrm{C}\right)$. Alternatively, the $\mathrm{Ni}$-rich phase could be horomanite, a Ni-Fe sulfide stable to $760{ }^{\circ} \mathrm{C}$ (Kitakaze et al. 2011). Pentlandite also occurs as oriented, flame-shaped grains in Mss in coarse-grained and zoned droplets (Figs. 3, 4). Kelly \& Vaughan (1983) interpreted these to have exsolved by homogeneous nucleation during Mss annealing from 600 to $300{ }^{\circ} \mathrm{C}$. 


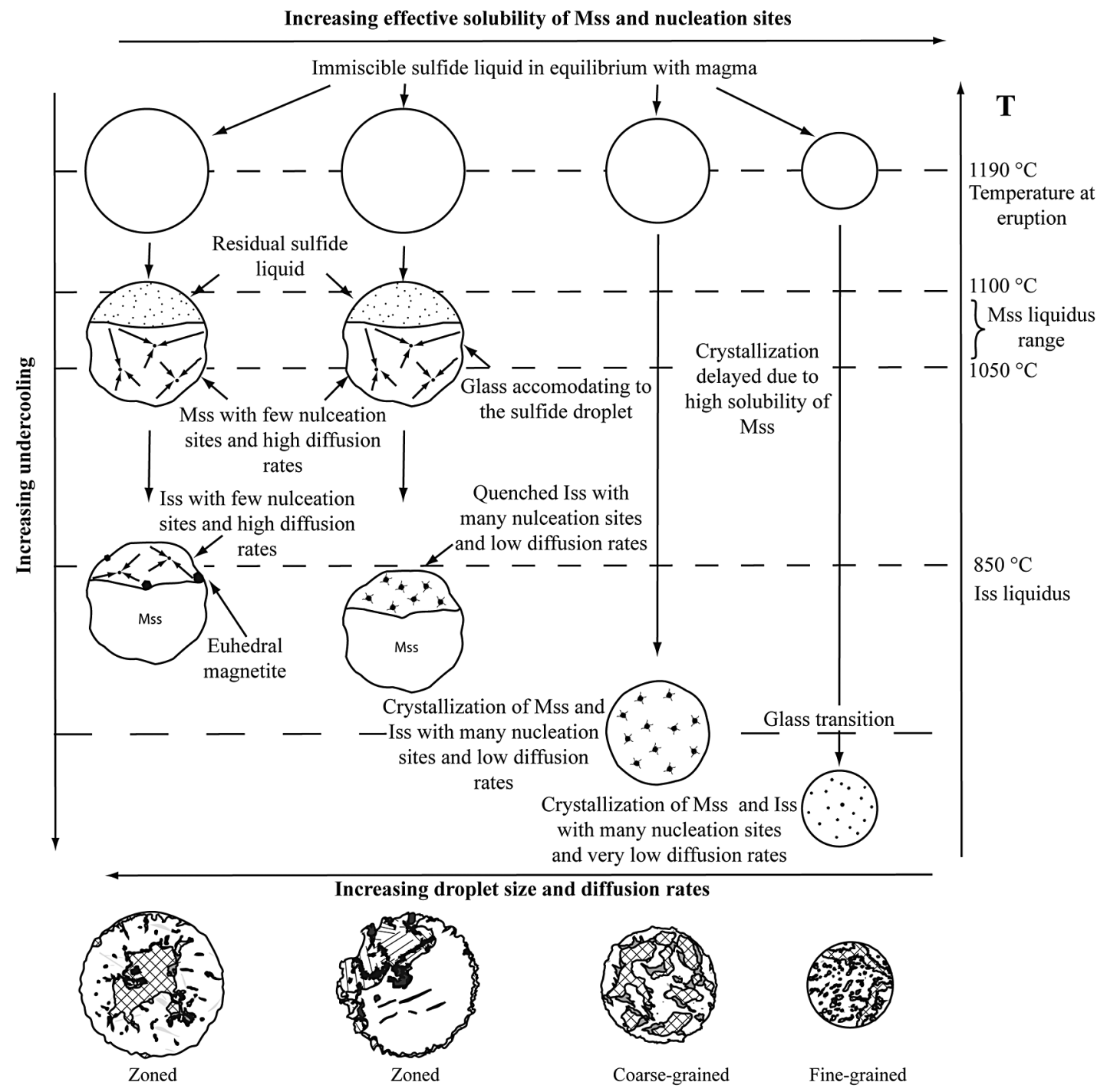

FIG. 7. Illustration of the dependency of sulfide droplet cooling history on droplet size. Mss effective solubility increases in droplets as the size decreases leading to a delay in sulfide crystallization during cooling.

\section{CONCLUSIONS}

The textural study of quenched sulfide droplets from fresh MORB glass leads to the following conclusions: (1) Textural differences observed in droplets that experienced identical cooling rates are due to differences in the degree of undercooling of the droplets. (2) The differences are mainly controlled by the size of the droplets. In the smaller droplets the effective solubility of Mss is higher, and higher degrees of undercooling are required for crystallization to occur. The effective solubility decreases as droplet size increases. (3) Bulk $\mathrm{Fe}, \mathrm{Ni}$, and $\mathrm{Cu}$ contents of the sulfide droplets do not seem to influence their texture. (4) The amount of pentlandite in sulfide droplets is controlled by the $\mathrm{Ni}$ concentration of the magma.

Sulfide droplets in MORB are unique records of near-liquidus phase relations in basaltic systems and provide unique insight into how sulfide-oxide liquids solidify under conditions of rapid cooling. Such insight may be useful in understanding how siderophile and 
chalcophile elements behave during sulfide crystallization in ore deposits.

\section{ACKNOWLEDGMENTS}

We are grateful to Jim Mungall (University of Toronto) and Bob Martin (McGill University) for the very helpful comments during the reviewing process. Sarah Dare (UQAC) and Philippe Pagé (UQAC) are thanked for helpful discussions, George Lozefski of Lamont Doherty Earth Observatory of Columbia University for his assistance with sampling, Dany Savard (UQAC) for his assistance with whole rock analyses and Marc Choquette (Laval University) for his assistance with microprobe analyses. This work was funded by the Canadian Research Chair in Magmatic Metallogeny.

\section{APPENDIX}

\section{Appendix 1: Sulfide droplets bulk composition calculations}

Sulfide droplet bulk compositions were calculated to $100 \%$ sulfide with the Image Pro Plus Analysis 6.2 software and the microprobe analyses data using for each element:

$$
\begin{aligned}
C_{s}= & \left(\frac{\Sigma^{n 1} C_{F e} \text { phase }}{n 1}\right) * \% \text { Fe phase }+ \\
& \left(\frac{\Sigma^{n 2} C_{C u} \text { phase }}{n 2}\right) * \% \text { Cu phase }+ \\
& \left(\frac{\Sigma^{n 3} C_{N i \text { phase }}}{n 3}\right) * \% \text { Ni phase }
\end{aligned}
$$

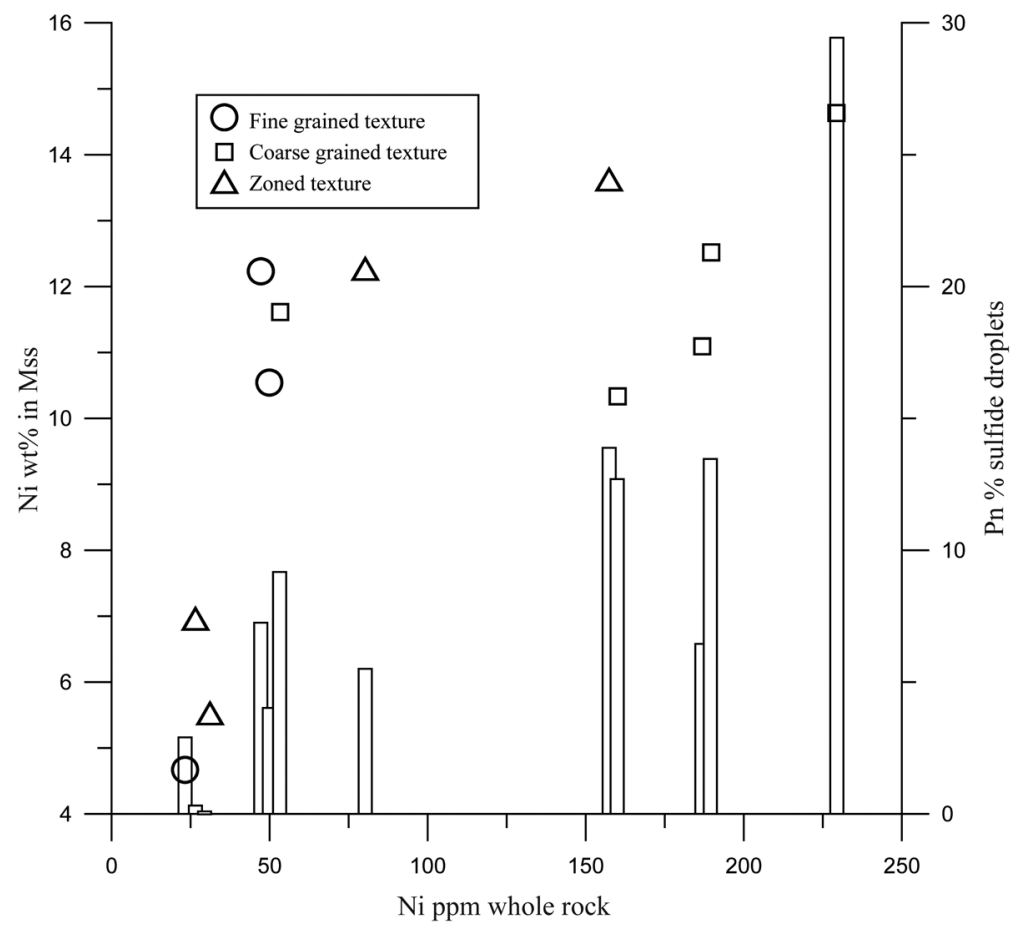

FIG. 8. Ni content of Mss (symbols) and pentlandite content (bars) of corresponding sulfide droplet versus $\mathrm{Ni}$ whole rock content. Overlapping bars refer to droplets from the same sample. Note that Ni concentration in Mss reaches a limit at $12-15 \%$ and that pentlandite concentration increases when this limit is reached. Data are from Table 3; only sulfide droplets with pentlandite content determined by Image Pro Analysis 6.2 are plotted. 
where $C_{S}, C_{F e}$ phase,$C_{C u \text { phase }}$, and $C_{N i \text { phase }}$ are the concentration of the element in the sulfide droplet, the Fe-rich phase, the $\mathrm{Cu}$-rich phase, and the Ni-rich phase, respectively. $\mathrm{n} 1, \mathrm{n} 2$, and $\mathrm{n} 3$ are the number of electron microprobe analyses for each phase. The $\% \mathrm{Fe}$ phase, \% Cu phase, and \%Ni phase are the percentages of each phase determined by Image Pro Plus Analysis 6.2. Bulk compositions are calculated to $100 \%$ sulfide to be in agreement with the experiments at values of Ebel \& Naldrett (1997), which are oxide free; S and $\mathrm{Fe}$ concentrations are slightly overestimated, as the proportion of oxide occurrences varies from nil to $7 \%$ in sulfide droplets. Detailed calculations of the Table 2 values are given in Table 3 . As Ni-rich phases are present in sulfide droplets either as micrometric flameshaped exsolution domains or as micrometric grains at the $\mathrm{Fe}$-rich and $\mathrm{Cu}$-rich boundaries, their analyses by microprobe was not possible in all droplets. Where a direct analysis of the Ni-rich phase was impossible, the average composition of the Ni-rich phase $(n=5)$ was used for the calculation of the bulk composition determined at $33.4 \% \mathrm{~S}( \pm 1.32), 38.64 \% \mathrm{Fe}( \pm 4.72)$, $24 \% \mathrm{Ni}( \pm 4.87)$ and $2.6 \% \mathrm{Cu}( \pm 1.47)$. For fine-grained sulfide droplets, the phases are too small to be analyzed independently, and the average composition of the whole droplet is used for calculation.

Appendix 2: Whole-rock Ni values

Fresh glass rims of pillow samples were crushed in an Al-ceramic mill at UQAC for whole-rock Ni analyses. The Ni content was determined by atomic absorption spectrometry (AAS) at LabMaTer, UQAC using a Thermo Atomic Spectrometer (Table 4). KPT reference material was used as monitor.

\section{Appendix 3: Composition of oxide inclusions in sulfide droplets}

Euhedral magnetites in sulfide droplets with a size large enough for an electron-microprobe analysis are rare; their compositions are given in Table 5. Three

\begin{tabular}{|c|c|c|c|c|c|c|c|c|c|c|c|c|c|c|c|c|}
\hline \multirow[t]{3}{*}{ Droplet } & \multirow[t]{3}{*}{ Texture } & \multirow{3}{*}{$\begin{array}{l}\text { Size } \\
(\mu \mathrm{m})\end{array}$} & \multirow[t]{3}{*}{ Phase } & \multicolumn{5}{|c|}{ Microprobe analysis } & \multicolumn{3}{|c|}{ Image pro $100 \%$ sulf } & \multicolumn{5}{|c|}{ Bulk composition } \\
\hline & & & & $S$ & $\mathrm{Ni}$ & $\mathrm{Cu}$ & $\mathrm{Fe}$ & Total & Fe-rich & Cu-rich & Ni-rich & $\mathrm{S}$ & $\mathrm{Ni}$ & $\mathrm{Cu}$ & $\mathrm{Fe}$ & Total \\
\hline & & & & wt. $\%$ & wt.\% & wt.\% & wt. $\%$ & wt. $\%$ & & & & wt.\% & wt. \% & wt. \% & wt. \% & wt. \% \\
\hline \multicolumn{17}{|c|}{ South Atlantic Ridge } \\
\hline \multirow[t]{9}{*}{$\begin{array}{l}\mathrm{RC} 2802 \\
\text { 07rd G1 }\end{array}$} & $\begin{array}{l}\text { Coarse- } \\
\text { grained }\end{array}$ & 48.0 & Ni-rich & 31.3 & 27.4 & 5.0 & 34.0 & 98.0 & 31.0 & 39.5 & 29.4 & 34.5 & 15.9 & 11.4 & 37.2 & 99.0 \\
\hline & & & Fe-rich & 36.0 & 14.5 & 2.6 & 46.4 & 99.7 & & & & 0.90 & 3.91 & 1.86 & 1.93 & \\
\hline & & & Cu-rich & 34.0 & 1.2 & 28.4 & 31.0 & 94.7 & & & & & & & & \\
\hline & & & Cu-rich & 34.4 & 12.2 & 23.7 & 30.3 & 100.8 & & & & & & & & \\
\hline & & & Ni-rich & 32.7 & 31.7 & 3.5 & 32.1 & 100.2 & & & & & & & & \\
\hline & & & Cu-rich & 34.4 & 12.2 & 21.4 & 31.4 & 99.6 & & & & & & & & \\
\hline & & & Fe-rich & 36.5 & 15.5 & 1.7 & 46.3 & 100.4 & & & & & & & & \\
\hline & & & Fe-rich & 35.5 & 13.9 & 2.1 & 47.4 & 99.1 & & & & & & & & \\
\hline & & & Ni-rich & 35.2 & 22.6 & 1.9 & 40.9 & 100.7 & & & & & & & & \\
\hline \multirow{4}{*}{$\begin{array}{c}\mathrm{RC} 2802 \\
\text { 13rd n1 G6 }\end{array}$} & Zoned & 63.0 & Cu-rich & 35.5 & 0.3 & 26.2 & 38.5 & 100.7 & 47.1 & 47.4 & 5.5 & 34.0 & 6.4 & 12.0 & 41.9 & 94.3 \\
\hline & & & Cu-rich & 33.0 & 2.2 & 22.5 & 40.8 & 98.6 & & & & 0.99 & 0.71 & 1.52 & 0.87 & \\
\hline & & & Fe-rich & 37.9 & 12.3 & 0.7 & 49.3 & 100.4 & & & & & & & & \\
\hline & & & Fe-rich & 37.5 & 12.2 & 1.3 & 49.1 & 100.4 & & & & & & & & \\
\hline \multirow{2}{*}{$\begin{array}{c}\text { RC } 2802 \\
\text { 13rd n1 G10 }\end{array}$} & Fine- & 29.0 & w.d. & 36.2 & 9.0 & 1.4 & 51.3 & 98.1 & & & & 35.6 & 8.9 & 2.7 & 50.4 & 97.6 \\
\hline & & & w.d. & 35.0 & 8.8 & 3.9 & 49.5 & 97.7 & & & & 0.89 & 0.13 & 1.78 & 1.24 & \\
\hline \multirow{3}{*}{$\begin{array}{c}\text { RC } 2802 \\
\text { 13rd n2 G1 }\end{array}$} & Fine- & 28.0 & w.d. & 34.4 & 8.8 & 3.3 & 48.7 & 95.5 & & & & 35.0 & 8.3 & 3.6 & 48.9 & 95.8 \\
\hline & & & w.d. & 35.1 & 8.5 & 4.6 & 47.7 & 96.1 & & & & 0.54 & 0.65 & 0.83 & 1.24 & \\
\hline & & & w.d. & 35.4 & 7.6 & 3.0 & 50.2 & 96.5 & & & & & & & & \\
\hline \multirow{3}{*}{$\begin{array}{c}\text { RC } 2802 \\
\text { 13rd n2 G2 }\end{array}$} & Fine- & 13.0 & w.d. & 36.0 & 8.8 & 5.1 & 48.3 & 98.5 & & & & 35.6 & 8.9 & 5.0 & 48.6 & 98.1 \\
\hline & & & w.d. & 35.0 & 9.8 & 6.2 & 46.8 & 98.1 & & & & 0.52 & 0.85 & 1.34 & 1.99 & \\
\hline & & & w.d. & 35.8 & 8.2 & 3.6 & 50.7 & 98.4 & & & & & & & & \\
\hline
\end{tabular}


TABLE 3B. BULK COMPOSITION OF THE SULPHIDE DROPLETS CALCULATED WITH MICROPROBE AND IMAGE PRO PLUS ANALYSIS DATA. BULK COMPOSITION IS EITHER CALCULATED WITH (1) WHOLE DROPLET MICROPROBE ANALYSIS AVERAGE OR (2) EQUATION [6].

\begin{tabular}{|c|c|c|c|c|c|c|c|c|c|c|c|c|c|c|c|c|}
\hline \multirow[t]{3}{*}{ Droplet } & \multirow[t]{3}{*}{ Texture } & \multirow{3}{*}{$\begin{array}{l}\text { Size } \\
(\mu \mathrm{m})\end{array}$} & \multirow[t]{3}{*}{ Phase } & \multicolumn{5}{|c|}{ Microprobe analysis } & \multicolumn{4}{|c|}{ Image pro $100 \%$ sulf } & \multicolumn{4}{|c|}{ Bulk composition } \\
\hline & & & & $\mathrm{S}$ & $\mathrm{Ni}$ & $\mathrm{Cu}$ & $\mathrm{Fe}$ & Total & Fe-rich & Cu- & Ni-rich & $\mathrm{S}$ & $\mathrm{Ni}$ & $\mathrm{Cu}$ & $\mathrm{Fe}$ & Total \\
\hline & & & & wt. $\%$ & wt. $\%$ & wt. $\%$ & wt. \% & wt. $\%$ & & & & wt. \% & wt. $\%$ & wt. $\%$ & wt. $\%$ & wt. \% \\
\hline \multirow{3}{*}{$\begin{array}{c}\text { RC } 2802 \\
\text { 13rd n2 G3 }\end{array}$} & Fine- & 12.0 & w.d. & 35.3 & 10.0 & 4.6 & 48.1 & 98.1 & & & & 35.7 & 9.4 & 3.7 & 48.9 & 97.6 \\
\hline & & & w.d. & 35.5 & 8.9 & 3.4 & 49.4 & 97.4 & & & & 0.51 & 0.55 & 0.75 & 0.68 & \\
\hline & & & w.d. & 36.2 & 9.2 & 3.1 & 49.2 & 98.0 & & & & & & & & \\
\hline \multirow{3}{*}{$\begin{array}{c}\mathrm{RC} 2802 \\
\text { 16d n1 G10 }\end{array}$} & Fine- & 45.0 & Fe-rich & 34.9 & 4.6 & 6.2 & 51.0 & 97.1 & 49.3 & 47.8 & 2.9 & 32.7 & 2.8 & 14.4 & 44.4 & 94.4 \\
\hline & & & Cu-rich & 32.8 & 1.0 & 23.0 & 40.5 & 97.7 & & & & 0.44 & 0.03 & 1.10 & 0.28 & \\
\hline & & & Fe-rich & 34.2 & 4.7 & 7.7 & 50.6 & 97.6 & & & & & & & & \\
\hline \multirow{3}{*}{$\begin{array}{c}\text { RC } 2802 \\
\text { 16rd n1 G3 }\end{array}$} & Fine- & 21.0 & w.d. & 34.5 & 3.2 & 11.9 & 46.6 & 96.5 & & & & 34.5 & 3.6 & 11.3 & 47.1 & 96.4 \\
\hline & & & w.d. & 34.3 & 3.1 & 13.8 & 45.5 & 97.0 & & & & 0.26 & 0.66 & 2.87 & 1.85 & \\
\hline & & & w.d. & 34.8 & 4.3 & 8.2 & 49.1 & 96.7 & & & & & & & & \\
\hline \multirow{3}{*}{$\begin{array}{c}\mathrm{RC} 2802 \\
\text { 16rd n1 G4 }\end{array}$} & Fine- & 25.0 & w.d. & 34.6 & 4.7 & 7.7 & 49.5 & 96.8 & & & & 34.8 & 4.4 & 7.5 & 50.1 & 96.9 \\
\hline & & & w.d. & 34.6 & 4.3 & 7.3 & 50.5 & 96.9 & & & & 0.34 & 0.28 & 0.17 & 0.59 & \\
\hline & & & w.d. & 35.2 & 4.3 & 7.6 & 50.4 & 97.7 & & & & & & & & \\
\hline \multirow{2}{*}{$\begin{array}{c}\text { RC } 2802 \\
\text { 16rd n2 G2 }\end{array}$} & Zoned & 18.0 & Cu-rich & 31.3 & 0.8 & 18.1 & 44.8 & 95.1 & 71.0 & 29.0 & 0.0 & 32.4 & 2.2 & 13.9 & 47.0 & 95.5 \\
\hline & & & Fe-rich & 35.2 & 5.5 & 3.8 & 52.4 & 97.2 & & & & & & & & \\
\hline \multirow{3}{*}{$\begin{array}{l}\text { RC } 2802 \\
\text { 16rd n2 G6 }\end{array}$} & Fine- & 20.0 & w.d. & 33.7 & 4.2 & 10.8 & 48.5 & 97.4 & & & & 33.7 & 3.1 & 15.5 & 45.0 & 97.3 \\
\hline & & & w.d. & 33.9 & 3.4 & 15.5 & 44.7 & 97.7 & & & & 0.20 & 1.25 & 4.70 & 3.37 & \\
\hline & & & w.d. & 33.5 & 1.7 & 20.2 & 41.8 & 97.4 & & & & & & & & \\
\hline \multirow{4}{*}{$\begin{array}{c}\mathrm{RC} 2802 \\
18 \mathrm{rd} \mathrm{G5}\end{array}$} & Fine- & 70.0 & Cu-rich & 35.8 & 1.4 & 21.7 & 40.7 & 99.8 & 80.6 & 19.1 & 0.3 & 37.7 & 6.0 & 4.4 & 51.6 & 99.7 \\
\hline & & & Cu-rich & 35.6 & 2.9 & 19.5 & 41.8 & 99.9 & & & & 0.16 & 0.55 & 0.89 & 0.73 & \\
\hline & & & Fe-rich & 38.2 & 6.9 & 0.7 & 54.8 & 101.0 & & & & & & & & \\
\hline & & & Fe-rich & 38.4 & 7.0 & 0.4 & 53.8 & 99.9 & & & & & & & & \\
\hline
\end{tabular}

TABLE 3C. BULK COMPOSITION OF THE SULPHIDE DROPLETS CALCULATED WITH MICROPROBE AND IMAGE PRO PLUS ANALYSIS DATA. BULK COMPOSITION IS EITHER CALCULATED WITH (1) WHOLE DROPLET MICROPROBE ANALYSIS AVERAGE OR (2) EQUATION [6].

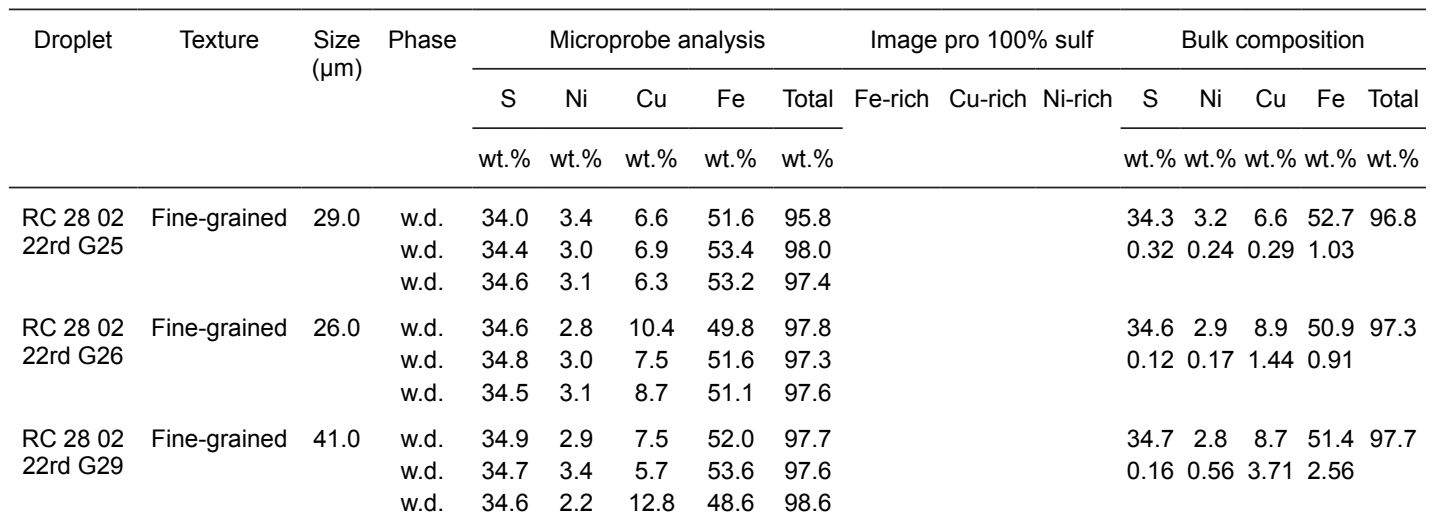




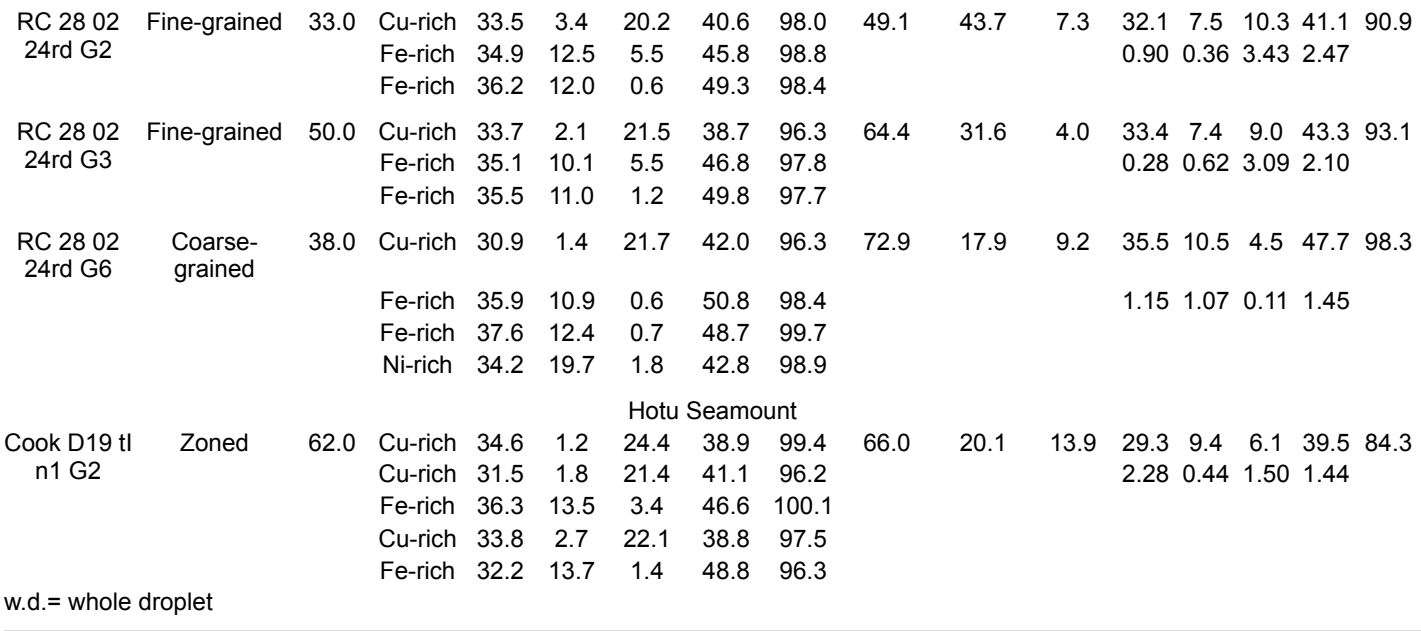

TABLE 3D. BULK COMPOSITION OF THE SULPHIDE DROPLETS CALCULATED WITH MICROPROBE AND IMAGE PRO PLUS ANALYSIS DATA. BULK COMPOSITION IS EITHER CALCULATED WITH (1) WHOLE DROPLET MICROPROBE ANALYSIS AVERAGE OR (2) EQUATION [6].

\begin{tabular}{|c|c|c|c|c|c|c|c|c|c|c|c|c|c|c|c|c|}
\hline \multirow[t]{3}{*}{ Droplet } & \multirow[t]{3}{*}{ Texture } & \multirow{3}{*}{$\begin{array}{l}\text { Size } \\
(\mu \mathrm{m})\end{array}$} & \multirow[t]{3}{*}{ Phase } & \multicolumn{5}{|c|}{ Microprobe analysis } & \multicolumn{3}{|c|}{ Image pro $100 \%$ sulf } & \multicolumn{5}{|c|}{ Bulk composition } \\
\hline & & & & $S$ & $\mathrm{Ni}$ & $\mathrm{Cu}$ & $\mathrm{Fe}$ & Total & Fe-rich & Cu-rich & Ni-rich & S & $\mathrm{Ni}$ & $\mathrm{Cu}$ & $\mathrm{Fe}$ & Total \\
\hline & & & & wt. $\%$ & wt. $\%$ & wt. $\%$ & wt. \% & wt.\% & & & & wt. \% & wt.\% & wt. $\%$ & wt. $\%$ & wt. \% \\
\hline \multicolumn{17}{|c|}{ East Pacific Rise } \\
\hline \multirow{4}{*}{$\begin{array}{c}\text { Cook D28 tl } \\
\text { n1 G1 }\end{array}$} & \multirow{4}{*}{$\begin{array}{l}\text { Coarse- } \\
\text { grained }\end{array}$} & \multirow[t]{4}{*}{32.0} & Fe-rich & 36.3 & 11.5 & 4.0 & 47.7 & 99.8 & 44.5 & 49.0 & 6.5 & 33.4 & 9.2 & 4.3 & 45.2 & 92.2 \\
\hline & & & Fe-rich & 34.1 & 9.9 & 1.9 & 50.5 & 96.6 & & & & 1.45 & 1.09 & 1.63 & 1.37 & \\
\hline & & & Cu-rich & 33.2 & 1.2 & 20.6 & 44.6 & 99.6 & & & & & & & & \\
\hline & & & Fe-rich & 36.8 & 11.9 & 0.8 & 49.1 & 98.8 & & & & & & & & \\
\hline \multirow{4}{*}{$\begin{array}{c}\text { Cook D28 tl } \\
\text { n2 G1 }\end{array}$} & \multirow{4}{*}{$\begin{array}{l}\text { Coarse- } \\
\text { grained }\end{array}$} & \multirow[t]{4}{*}{42.0} & Cu-rich & 34.6 & 7.6 & 19.4 & 39.3 & 101.4 & 43.6 & 43.0 & 13.5 & 30.0 & 8.0 & 9.4 & 38.3 & 85.7 \\
\hline & & & Fe-rich & 36.0 & 12.0 & 1.2 & 49.0 & 98.4 & & & & 1.04 & 1.92 & 1.19 & 0.18 & \\
\hline & & & Fe-rich & 35.6 & 13.1 & 0.9 & 49.0 & 99.1 & & & & & & & & \\
\hline & & & Cu-rich & 32.4 & 4.3 & 22.2 & 39.7 & 98.8 & & & & & & & & \\
\hline \multirow{5}{*}{$\begin{array}{l}\text { Cook D37 } \\
\text { tIV G2 }\end{array}$} & \multirow{5}{*}{$\begin{array}{l}\text { Coarse- } \\
\text { grained }\end{array}$} & \multirow[t]{5}{*}{32.0} & Cu-rich & 35.0 & 2.9 & 26.5 & 36.5 & 101.1 & 53.1 & 34.2 & 12.7 & 35.2 & 8.9 & 10.1 & 44.5 & 98.6 \\
\hline & & & Fe-rich & 37.0 & 11.0 & 1.1 & 49.3 & 98.7 & & & & 1.32 & 0.72 & 0.85 & 0.57 & \\
\hline & & & Fe-rich & 34.3 & 9.6 & 2.6 & 50.4 & 97.2 & & & & & & & & \\
\hline & & & Fe-rich & 35.5 & 10.5 & 1.3 & 49.8 & 97.4 & & & & & & & & \\
\hline & & & Ni-rich & 33.6 & 18.8 & 0.8 & 43.5 & 97.3 & & & & & & & & \\
\hline \multirow{3}{*}{$\begin{array}{l}\text { Cook D37 } \\
\text { tVI n2 G1 }\end{array}$} & \multirow{3}{*}{$\begin{array}{l}\text { Coarse- } \\
\text { grained }\end{array}$} & \multirow[t]{3}{*}{20.0} & w.d. & 34.5 & 12.4 & 4.7 & 44.3 & 96.1 & & & & 35.0 & 11.3 & 4.8 & 45.6 & 96.8 \\
\hline & & & w.d. & 35.1 & 11.0 & 3.4 & 46.5 & 96.2 & & & & 0.56 & 0.92 & 1.42 & 1.14 & \\
\hline & & & w.d. & 35.6 & 10.6 & 6.2 & 46.0 & 98.8 & & & & & & & & \\
\hline \multirow{3}{*}{$\begin{array}{l}\text { Cook D37 } \\
\text { tVI n2 G3 }\end{array}$} & \multirow{3}{*}{$\begin{array}{l}\text { Fine- } \\
\text { grained }\end{array}$} & \multirow[t]{3}{*}{13.0} & w.d. & 35.1 & 7.8 & 13.6 & 42.6 & 99.4 & & & & 35.1 & 9.3 & 11.8 & 43.3 & 99.4 \\
\hline & & & w.d. & 35.0 & 11.7 & 7.5 & 44.9 & 99.3 & & & & 0.10 & 2.09 & 3.75 & 1.45 & \\
\hline & & & w.d. & 35.2 & 8.3 & 14.3 & 42.2 & 100.2 & & & & & & & & \\
\hline \multirow[t]{3}{*}{$\begin{array}{l}\text { Cook D37 } \\
\text { tVI n3 G8 }\end{array}$} & \multirow{3}{*}{$\begin{array}{l}\text { Fine- } \\
\text { grained }\end{array}$} & \multirow[t]{3}{*}{15.0} & w.d. & 34.7 & 11.9 & 7.8 & 43.5 & 98.1 & & & & 35.1 & 11.0 & 8.4 & 43.6 & 98.1 \\
\hline & & & w.d. & 35.5 & 11.3 & 8.1 & 43.2 & 98.3 & & & & 0.39 & 1.11 & 0.75 & 0.43 & \\
\hline & & & w.d. & 35.2 & 9.8 & 9.2 & 44.1 & 98.4 & & & & & & & & \\
\hline w.d. $=$ whol & Upiet & & & & & & & & & & & & & & & \\
\hline
\end{tabular}


TABLE 4. WHOLE-ROCK VALUES OF NI DONE BY AAS

\begin{tabular}{cccc}
\hline Sample & $\begin{array}{c}\mathrm{Ni} \\
(\mathrm{ppm})\end{array}$ & Sample & $\begin{array}{c}\mathrm{Ni} \\
(\mathrm{ppm})\end{array}$ \\
\hline RC 2802 07rd & 229 & Cook D3 tIII & 101 \\
RC 2802 13rd & 80 & Cook D19 tl n1 & 157 \\
RC 2802 16rd & 23 & Cook D28 tl & 187 \\
RC 2802 18rd & 26 & Cook D37 tIV & 165 \\
RC 28 02 22rd & 30 & Cook D37 tVI & 195 \\
RC 28 02 24rd & 47 & KPT $(n=3)$ & $1006+/-11$ \\
& & KPT working values & $1090+/-149$ \\
\hline
\end{tabular}

TABLE 5. EUHEDRAL OXIDE MICROPROBE ANALYSES FROM SULFIDE DROPLETS

\begin{tabular}{|c|c|c|c|c|c|c|c|c|c|c|c|}
\hline Droplet & $\begin{array}{l}\mathrm{SiO}_{2} \\
\text { wt.\% }\end{array}$ & $\begin{array}{l}\mathrm{TiO}_{2} \\
\text { wt. \% }\end{array}$ & $\begin{array}{l}\mathrm{Al}_{2} \mathrm{O}_{3} \\
\text { wt. } \%\end{array}$ & $\begin{array}{c}\mathrm{Fe}_{2} \mathrm{O}_{3} \\
\text { wt. \% }\end{array}$ & $\begin{array}{l}\mathrm{FeO} \\
\text { wt.\% }\end{array}$ & $\begin{array}{l}\text { MnO } \\
\text { wt. \% }\end{array}$ & $\begin{array}{l}\mathrm{MgO} \\
\text { wt. } \%\end{array}$ & $\begin{array}{l}\mathrm{CaO} \\
\text { wt. } \%\end{array}$ & $\begin{array}{c}\mathrm{NiO} \\
\text { wt.\% }\end{array}$ & $\begin{array}{l}\mathrm{ZnO} \\
\text { wt.\% }\end{array}$ & $\begin{array}{l}\text { Total } \\
\text { wt. } \%\end{array}$ \\
\hline RC 2802 13rd n1 G6 & 0.20 & 0.02 & 0.01 & 63.25 & 23.63 & 0.24 & 0.00 & 0.05 & 4.65 & 0.12 & 92.25 \\
\hline Cook D19 tl n1 G2 & 0.05 & 0.00 & 0.01 & 56.40 & 10.09 & 0.07 & 0.00 & 0.30 & 15.48 & 0.01 & 82.45 \\
\hline RC 2802 18rd G5 & 0.47 & 0.05 & 0.06 & 57.89 & 17.50 & 0.02 & 0.00 & 0.28 & 8.72 & 0.02 & 85.32 \\
\hline$\sigma(n=2)$ & 0.05 & 0.05 & 0.03 & 1.40 & 1.82 & 0.01 & 0.00 & 0.01 & 2.80 & 0.02 & 2.58 \\
\hline
\end{tabular}

Note the high $\mathrm{NiO}$ values due to sulfide contamination. Oxides are Ti-free magnetite.

of them were analyzed and gave poor values. Moreover, there is a high contamination by the surrounding sulfide owing to secondary fluorescence traduced by high concentration in Ni. However, the results allow a qualitative interpretation as they leave no doubt that the grains are Ti-free magnetite.

\section{REFERENCES}

BARnes, S.-J., Cox, R.A., \& ZiEnTeK, M.L. (2006) Platinumgroup element, gold, silver and base metal distribution in compositionally zoned sulfide droplets from the Medvezky Creek Mine, Noril'sk, Russia. Contributions to Mineralogy and Petrology 152, 187-200.

BIGG, E.K. (1953) The supercooling of water. Proceedings of the Physical Society 66b, 688-694.

Boudreau, A.E. (1999) PELE - a version of the MELTS software program for the PC platform. Computers \& Geosciences 25, 201-203.

Cashman, K.V. \& Marsh, B.D. (1988) Crystal size distribution (CSD) in rocks and the kinetics and dynamics of crystallization II: Makaopuhi lava lake. Contributions to Mineralogy and Petrology 99, 292-305.

Craig, J.R. \& Kullerud, G. (1969) Phase relations in the $\mathrm{Cu}-\mathrm{Fe}-\mathrm{Ni}-\mathrm{S}$ system and their application to magmatic ore deposits. Economic Geology Monograph 4, 344-358.
Czamanske, G.K. \& Moore, J.G. (1977) Composition and phase chemistry of sulfide globules in basalt in the MidAtlantic Ridge rift valley near $37^{\circ} \mathrm{N}$ lat. Geological Society of America Bulletin 88, 587-599.

Dalton, J.A. \& LANE, S.J. (1996) Electron microprobe analysis of $\mathrm{Ca}$ in olivine close to grain boundaries: the problem of secondary X-ray fluorescence. American Mineralogist 81, 194-201.

DowTy, E. (1980) Crystal growth and nucleation theory and the numerical simulation of igneous crystallization. In Physics of magmatic processes (R.B. Hargraves, ed.), 419-485p.

Ebel, D.S. \& NALDRETT, A.J. (1997) Crystallization of sulfide liquids and the interpretation of ore composition. Canadian Journal of Earth Sciences 34, 352-365.

Emmanuel, S., Ague, J. J., \& Walderhaug, O. (2010) Interfacial energy effects and the evolution of pore size distributions during quartz precipitation in sandstone. Geochimica et Cosmochimica Acta, 74, 3539-3552.

Etschmann, B., Pring, A., Putnis, A., Grguric, B.A., \& A. STUdER. (2004) A kinetic study of the exsolution of pentlandite $(\mathrm{Ni}, \mathrm{Fe})^{9} \mathrm{~S}^{8}$ from the monosulfide solid solution (Fe,Ni) S. American Mineralogist 89, 39-50.

FLeET, M.E. \& PAN, Y. (1994) Fractional crystallization of anhydrous sulfide liquid in the system $\mathrm{Fe}-\mathrm{Ni}-\mathrm{Cu}-\mathrm{S}$, with application to magmatic sulfide deposits. Geochimica et Cosmochimica Acta 58, 3369-3377. 
GIBB, F.G.F. (1974) Supercooling and the crystallization of plagioclase from a basaltic magma. Mineralogical Magazine 39, 641-653.

HigGins, M.D. (2006) Verification of ideal semi-logarithmic, lognormal or fractal crystal size distributions from 2D datasets. Journal of Volcanology and Geothermal Research 154, 8-16.

Holness, M.B. \& SAWyer, E.W. (2008) On the pseudomorphing of melt-filled pores during the crystallization of migmatites. Journal of Petrology 49, 1343-1363.

HolzheId, A. (2010) Separation of sulfide melt droplets in sulfur saturated silicate liquids. Chemical Geology 274, 127-135

Kelly, D.P. \& Vaughan, D.J. (1983) Pyrrhotine-pentlandite ore textures: a mechanistic approach. Mineralogical Magazine 47, 453-463.

Kitakaze, A., IтоH, H., \& Komatsu, R. (2011) Horomanite, (Fe, $\mathrm{Ni}, \mathrm{Co}, \mathrm{Cu})_{9} \mathrm{~S}_{8}$, and samaniite, $\mathrm{Cu}_{2}(\mathrm{Fe}, \mathrm{Ni})_{7} \mathrm{~S}_{8}$, new mineral species from the Horoman peridotite massif, Hokkaido, Japan. Journal of Mineralogical and Petrological Sciences 106, 204-210.

LiU, Y., SAmaHa, N., \& BAKER, D. (2007) Sulfur concentration at sulfide saturation (SCSS) in magmatic silicate melts. Geochimica et Cosmochimica Acta 71, 1783-1799.

Mathez, E.A. (1976) Sulfur solubility and magmatic sulfides in submarine basalt glass. Journal of Geophysical Research 81, 4269-4276.

MatheZ, E.A. (1979) Sulfide relations in hole 418A flows and sulfur contents of glasses. Initial reports of the Deep Sea Drilling Project 51, 1069-1085.

Mathez, E.A. \& YeAts, R.S. (1976) Magmatic sulfides in basalt glass from dsdp hole 319a and site 320, Nazca plate. Initial Reports of the Deep-Sea Drilling Project 34, 363-373.

Moore, J.G. (1975) Mechanism of formation of pillow lava. American Scientist 63, 269-277.

Moore, J.G. \& CALK, L.C. (1971) Sulfide spherules in vesicles of dredge pillow basalt. American Mineralogist 56, 476-488.

Moore, J.G. \& Schilling, J.G. (1973) Vesicles, water, and sulfur in Reykjanes Ridge basalt. Contribution to Mineralogy and Petrology 41, 105-118.

Mungall, J.E. (2002) Kinetic Controls on the Partitioning of Trace Elements Between Silicate and Sulfide Liquids. Journal of Petrology 43, 749-768.
Mungall, J.E. (2007) Crystallization of magmatic sulfides: An empirical model and application to Sudbury ores. Geochimica et Cosmochimica Acta 71, 2809-2819.

Mungall, J.E. \& Su, S. (2005) Interfacial tension between magmatic sulfide and silicate liquids: Constraints on kinetics of sulfide liquation and sulfide migration through silicate rocks. Earth and Planetary Science Letters 234, 135-149.

Mungall, J.E., Andrews, D.R.A., CABri, L.J., Sylvester, P.J., \& TubretT, M. (2005) Partitioning of $\mathrm{Cu}, \mathrm{Ni}, \mathrm{Au}$, and platinum-group elements between monosulfide solid solution and sulfide melt under controlled oxygen and sulfur fugacities. Geochimica et Cosmochimica Acta 69 , 4349-4360.

Naldrett, A.J. (1969) A Portion of the System Fe-S-0 between 900 and $1080^{\circ} \mathrm{C}$ and its Application to Sulfide Ore Magmas. Journal of Petrology 10, 171-201.

Peach, C.L., Mathez, E.A., \& Keays, R.R. (1990) Sulfide melt-silicate melt distribution coefficients for noble metals and other chalcophile elements as deduced from MORB: Implications for partial melting. Geochimica et Cosmochimica Acta 54, 3379-3389.

Prichard, H.M., Hutchinson, D., \& Fisher, P.C. (2004) Petrology and crystallization history of multiphase sulfide droplets in a mafic dike from Uruguay: implications for the origin of $\mathrm{Cu}-\mathrm{Ni}-\mathrm{PGE}$ sulfide deposits. Economic Geology 99, 365-376.

Putnis, A. \& Mauthe, G. (2001) The effect of pore size on cementation in porous rocks. Geofluids $\mathbf{1}, 37-41$.

SHELLEY, D. (1993) Igneous and metamorphic rocks under the microscope. Chapman and Hall, London.

SKINNER, B.J. \& PECK, D.L. (1969) An immiscible sulfide melt from Hawaï. Economic Geology Monograph 4, 310-320.

Wallace, P. \& CARmichael, I. (1992) Sulfur in basaltic magmas. Geochimica et Cosmochimica Acta 56, 1863-1874.

Yeats, R.S. \& MAthez, E.A. (1976) Decorated vesicles in deep-sea basalt glass, eastern pacific. Journal of Geophysical Research 81, 4277-4284.

Received October 4, 2011, revised manuscript accepted May 23, 2012. 